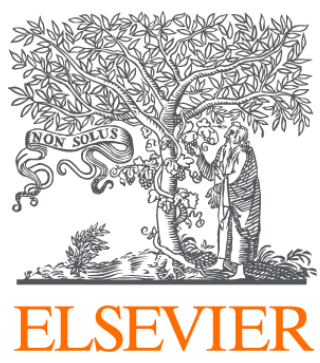

Since January 2020 Elsevier has created a COVID-19 resource centre with free information in English and Mandarin on the novel coronavirus COVID-

19. The COVID-19 resource centre is hosted on Elsevier Connect, the company's public news and information website.

Elsevier hereby grants permission to make all its COVID-19-related research that is available on the COVID-19 resource centre - including this research content - immediately available in PubMed Central and other publicly funded repositories, such as the WHO COVID database with rights for unrestricted research re-use and analyses in any form or by any means with acknowledgement of the original source. These permissions are granted for free by Elsevier for as long as the COVID-19 resource centre remains active. 


\title{
Inequality in household adaptation to schooling shocks: Covid-induced online learning engagement in real time
}

\author{
Andrew Bacher-Hicks ${ }^{\mathrm{a}, *}$, Joshua Goodman ${ }^{\mathrm{a}}$, Christine Mulhern ${ }^{\mathrm{b}}$ \\ ${ }^{a}$ Boston University, United States \\ ${ }^{\mathrm{b}}$ RAND Corporation, United States
}

\section{A R T I C L E I N F O}

\section{Article history:}

Received 10 July 2020

Revised 22 October 2020

Accepted 15 November 2020

Available online 14 December 2020

\section{Keywords:}

Online learning

COVID-19

Internet search

Google Trends

Pandemic

\begin{abstract}
A B S T R A C T
We use high frequency internet search data to study in real time how US households sought out online learning resources as schools closed due to the Covid-19 pandemic. By April 2020, nationwide search intensity for both school- and parent-centered online learning resources had roughly doubled relative to pre-Covid levels. Areas of the country with higher income, better internet access and fewer rural schools saw substantially larger increases in search intensity. The pandemic will likely widen achievement gaps along these dimensions given schools' and parents' differing engagement with online resources to compensate for lost school-based learning time. Accounting for such differences and promoting more equitable access to online learning could improve the effectiveness of education policy responses to the pandemic. The public availability of internet search data allows our analyses to be updated when schools reopen and to be replicated in other countries.
\end{abstract}

(c) 2020 Elsevier B.V. All rights reserved.

\section{Introduction}

As schools across the United States closed in response to the Covid-19 pandemic, roughly 55 million K-12 students experienced a serious disruption to their school year. Though most schools quickly began offering some type of virtual education (Hamilton et al., 2020; Lake and Dusseault, 2020), there have been growing concerns about the effects of this unprecedented shift (Malkus, 2020; von Hippel, 2020). In particular, there are fears that lowincome students will be unequally harmed by the shift to online learning, due to less access to online resources to compensate for lost in-person instruction (Horowitz, 2020). As states and districts consider how to best educate students in the wake of the pandemic, it is critical to better understand the effect of pandemicinduced school closures on students' access to online learning resources, particularly for low-income students.

This paper uses high frequency, nationally representative Google search data to document in real time how parents and students sought out online resources as schools closed in response to the Covid-19 pandemic. Combining the online search measures with

\footnotetext{
We thank Sara Ji and Jess Yang for their excellent research assistance. We received valuable feedback from seminar participants at Boston University, University of St. Andrews, IZA, Atlanta Federal Reserve, University of Chicago and NBER, as well as from Danny Yagan and two thoughtful anonymous referees.

* Corresponding author.

E-mail addresses: abhicks@bu.edu (A. Bacher-Hicks), edecjosh@bu.edu (J. Goodman), cmulhern@rand.org (C. Mulhern).
}

measures of demographic characteristics by geography, we use a difference-in-difference strategy to estimate how Covid-induced demand for online resources varied by a range of geographic and socioeconomic factors, including income, internet access and school rurality.

We document three findings new to the research literature. First, we show that pre-Covid search intensity for online learning resources can be usefully divided into two categories, which we call "school-centered resources" and "parent-centered resources". School-centered resources are platforms typically used by schools to provide instruction, assign work, or communicate with students (such as Google Classroom or Schoology). Parent-centered resources are more generic search terms likely indicating parents or students are seeking supplemental learning resources (such as home schooling or math worksheets). We show that search intensity for school-centered resources dwarfs that for parent-centered resources and that both follow the school calendar, peaking at the start of each school year and vanishing in the summer.

Second, we show that the onset of Covid dramatically disrupted this usual school calendar cycle of search intensity, as the pandemic triggered a very large increase in demand for online learning resources. By April 2020, nationwide search intensity for online learning resources had roughly doubled relative to pre-Covid levels. We find sharp increases in searches for both school- and parent-centered resources, suggesting that increased demand for online support came not only from schools shifting their mode of instruction but also from parents and students seeking additional support to fill learning gaps as schools closed. 
Third, we show the pandemic substantially widened socioeconomic gaps in searches for online learning resources. Search intensity rose twice as much in areas with above median socioeconomic status (measured by household income, parental education, and computer and internet access) as in areas with below median socioeconomic status. Search intensity for school-centered resources, for example, increased by 15 percent for each additional $\$ 10,000$ in mean household income and by roughly 5 percent for each percentage point increase in the fraction of households with broadband internet and a computer. Areas with more rural schools and Black students saw lower increases in search intensity. Socioeconomic gaps widened both between and within the country's four Census regions (Northeast, Midwest, South, and West). We also show that changes in search behavior correlate with changes in students' actual math progress, suggesting online search metrics may be a useful proxy for educational actions taken by parents and students.

Our work adds to three strands of the research literature. First, our paper shows that internet search behavior can provide useful, real-time information about education-related actions being taken by households. Prior work shows the utility of search data in predicting economic and social outcomes such as parents' preferences for schools (Schneider and Buckley, 2002), disease spread (Polgreen et al., 2008), consumer behavior (Choi Varian, 2012), voting (Stephens-Davidowitz, 2014), and fertility decisions (Kearney and Levine, 2015). Most recently, Goldsmith-Pinkham and Sojourner (2020) use the volume of online search for unemployment benefits to predict post-Covid unemployment claims. Our results suggest that search data contain valuable information about how households react to educational shocks, both in terms of overall use of educational resources and in heterogeneity in such usage by socioeconomic characteristics.

Second, we measure a new aspect of the digital divide, namely the extent to which households seek out online learning resources either prompted by their schools or of their own accord. A large literature documents pre-Covid gaps in access to and proficiency in the use of digital technologies by income, education, and family background (Bucy, 2000; Rice and Haythornthwaite, 2006; Jones et al., 2009; Vigdor et al., 2014). Multiple post-Covid surveys show consistent socioeconomic gaps in self-reported engagement with remote learning at a single point in time (Barnum and Bryan, 2020). We complement this evidence with the first nationally representative revealed preference measure of such engagement, based on households' actual behavior rather than self reports. Ours is also the first high frequency data brought to bear on this issue, allowing study of the evolution over time of engagement with online learning resources.

Third, we provide some of the clearest evidence on one channel through which the Covid-19 pandemic will likely widen socioeconomic educational gaps. Based on prior estimates of school closure effects from natural disasters and summer months, Kuhfeld et al. (2020) predict that Covid-induced closures will generate substantial learning losses, with the largest negative effects concentrated among low-achieving students. Aucejo et al. (2020) surveyed university students and find the pandemic lowered on-time graduation rates and job offers, with larger effects among low-income students. Using data from one online learning platform, Chetty et al. (2020) provide perhaps the only direct measure of Covidinduced learning loss, showing that low-income students experienced substantially larger and more persistent reductions in learning progress relative to high-income students. We show that

\footnotetext{
${ }^{1}$ In another example of how the pandemic exacerbated socioeconomic gaps in online forms of parental compensation for lost schooling time, Jæger and Blaabæk (2020) use Danish register data to show that pre-Covid income-based gaps in library e-book takeout rates further increased post-Covid.
}

socioeconomic gaps in engagement with online learning resources are not limited to a single platform or location but are a widespread and fundamental feature of the post-Covid landscape. Accounting for household responses to changing school inputs will be critical for predicting educational effects of the pandemic and policy responses to it, given evidence that parental and school investments are often substitutes, both in the US (Houtenville and Conway, 2008) and developing countries (Das et al., 2013; Pop-Eleches and Urquiola, 2013).

Our findings provide insight into the mechanisms underlying learning losses that are beginning to emerge following pandemic-induced school closures and can help inform future policy responses to schooling disruptions, whether related to the pandemic or not. That search for school-centered resources increases more in high income areas suggests either that those areas' schools are using online platforms more, that those areas' parents are more likely to engage with such platforms, or both. That search for parent-centered resources increases more in high income areas suggests that, separate from schools' actions, parents are differentially likely to seek out their own ways of compensating for their children's lost learning time.

These results can help policymakers and school leaders formulate more effective responses to the educational disruptions caused by Covid-induced school closures. Students from lower income families and schools may require additional attention and resources given lower engagement with online learning resources during spring 2020 . Moreover, because remote learning will likely remain a central piece of the public education system for the foreseeable future (Cleveland, 2020), preventing the widening of achievement gaps may require improving access to home computers and broadband internet for low income and rural students. Schools may also need to improve the deployment of remote learning platforms to more equitably engage students and parents in the use of those platforms.

Whether efforts to close gaps in online learning engagement succeed will only become clear as new data become available in subsequent school years. One advantage of using publicly available search data to measure household behavior is that our analyses can be easily updated in real time when the school year begins in the fall. This will help reveal whether socioeconomic gaps in engagement with online learning have narrowed since the initial shock of schools closing or if different remote learning strategies across regions were particularly successful. In addition, the set of search terms studied can be easily modified to accommodate new online learning resources as they emerge. Finally, our analyses can be replicated in other countries, particularly ones large enough to generate search data at sub-national levels such as provinces and cities. The flexibility of this approach shows promise for understanding the behavioral responses of households to school closures and developing policy responses in real time to address changing student needs.

\section{Data and empirical strategy}

\subsection{Data}

Our outcome measures of search intensity come from Google Trends, which makes publicly available weekly measures of internet search behavior both nationally and by Designated Market Area (DMA). DMAs, the finest geographic level at which search data are consistently available, are groups of counties, and 210 mutually exclusive DMAs span the United States. ${ }^{2}$ The publicly available

\footnotetext{
${ }^{2}$ DMAs are defined by Nielsen. For more information, see: https://www.
} nielsen.com/us/en/intl-campaigns/dma-maps/. 
measure of search behavior for a given term or topic is "search intensity", which calculates the fraction of a given area's Google searches devoted to that term or topic. Raw search volume and raw search intensity are not available. Instead, Google Trends normalizes measures of search intensity to allow for comparison of relative intensity over time and across DMAs. Given the challenge of interpreting such magnitudes, we often use the logarithm of search intensity so that estimates can be interpreted as percent changes. We implicitly assume increased search intensity for a term corresponds to increased raw search volume, given evidence that overall Google search volumes did not change substantially during the pandemic. ${ }^{3}$

We focus on measuring search intensity for terms related to online learning. We first assembled a list of 45 potential such keywords, downloaded five years of weekly search data from June 2015 through May 2020, and then ranked the keywords by their nationwide popularity. We then identified the 10 most popular keywords related to branded online learning resources (such as "Google Classroom" or "Khan Academy") and the ten most popular keywords for general online learning resources (such as "online learning", "home school", and "math worksheet"). Table 1 shows these lists and their popularity. ${ }^{4}$ The most popular of these search terms by far is Google Classroom. Khan Academy, one of the next most popular terms, was roughly 13 percent as popular as Google Classroom. ${ }^{5}$ General (non-branded) learning resources saw substantially lower search intensity than that.

We combine the ten items in each of these two lists to create two primary measures of search intensity for learning resources. We do so for three reasons. First, Google Trends does not publicly report search intensity if the total number of searches in a given area and week falls below a certain threshold, so combining search terms substantially reduces the amount of missing data. Second, we are more interested in the general level of demand for online learning resources rather than the popularity of any one resource. Third, Google Trends restricts the number of keywords whose total search intensity can be downloaded at one time, which requires us to focus on the most popular keywords. ${ }^{6}$ Therefore, our measure of search intensity aggregates the total popularity for the ten most popular keywords in DMA $d$ in week $t$ as follows

SearchIntensity $_{d t}=\sum_{i=1}^{10} \frac{\text { Google searches for }[\text { keyword } i]_{d t}}{\text { Total Google searches }{ }_{d t}}$.

Given the ten keywords in each list, we refer to branded learning resources as "school-centered resources" and general learning resources as "parent-centered resources". The former list largely

\footnotetext{
${ }^{3}$ One private firm, Statista, estimates that monthly US-based Google search volumes were 12.7 billion in April 2020, compared to 11.9 in January 2020, and that such search volumes have held fairly steady between 10 and 13 billion since 2015 . See "Number of explicit core search queries powered by search engines in the United States as of April 2020", accessed at https://www.statista.com/statistics/265796/ussearch-engines-ranked-by-number-of-core-searches through the Wayback Machine's July 17, 2020 archive.

4 For the full list of 45 keywords, see Table A.1. We identified 45 keywords related to $\mathrm{K}-12$ online learning resources through a combination of theory-driven and datadriven analysis. We began by identifying keywords that, in theory, relate to online learning, such as the searches for the major online learning platforms (such as "Google Classroom", "Khan Academy") and general searches for online learning resources (such as "online learning"). We augmented this with a data-driven approach by including additional keywords that were suggested as related by Google Trends. While it would have been possible to extend this list, we found the marginal return to each additional term was quite low. The top 3 keywords capture nearly 80 percent of the total pre-Covid search intensity and the top 10 capture nearly all of the total search intensity. Because the focus of the paper is on K-12 online learning, we excluded keywords related to professional services ("Webex"), textbooks ("Pearson"), postsecondary platforms ("Canvas"), or adult learning ("Masterclass").

${ }^{5}$ We normalize search intensity across keywords relative to the pre-Covid (MarchMay 2019) search intensity of Google Classroom.

${ }^{6}$ Nearly all of the search intensity for online learning is concentrated in the top 10 terms in each list as shown in Table A.1.
}

consists of educational platforms, such as Google Classroom and Schoology, that schools use to connect with students and are typically not used without the school's involvement. The latter list consists of general learning resources such as "math worksheets" and "home school", which we interpret as parents (or guardians or students themselves) searching for online learning resources on their own, without particular guidance from a school. ${ }^{7}$

To characterize the pre-Covid demographics of each DMA, we use county-level data from the 2016 American Community Survey (ACS) and then generate DMA-level measures as the populationweighted average across the counties within each DMA. ${ }^{8}$ We can therefore characterize DMAs by a variety of measures, including: mean household income; median household income; fraction of adults with a B.A.; fraction of households with broadband internet; and fraction of households with a computer. These five measures are so highly correlated that we refer to their population-weighted first principal component, which nearly equally weights each measure and explains 86 percent of their joint variation, as DMA-level socioeconomic status (SES). This allows us to do simple comparisons of search intensity across high and low SES areas of the country. We supplement ACS data with county-level data from the Stanford Education Data Archive (SEDA), which provides additional information such as the fraction of schools in rural areas and the racial composition of the school-age population. As of 2016, 27 percent of adults had a B.A., 23 percent lived in households without broadband internet access, and 25 percent of schools were in rural areas. ${ }^{9}$

\subsection{Empirical strategy}

We first estimate changes in nationwide search intensity for learning resources as a result of Covid-induced school closures, using both a week-by-week event study specification and a twoperiod before-after specification. The event study specification is

$$
\begin{aligned}
\log \left(\text { SearchIntensity }_{t}\right)= & \sum_{t=-39}^{-1} \beta_{t} \text { Before }_{t}+\sum_{t=1}^{12} \beta_{t} \text { After }_{t} \\
& +\alpha \text { PriorYears }_{t}+\mu_{w(t)}+\lambda_{y(t)}+\varepsilon_{t},
\end{aligned}
$$

where we regress on a vector of week indicators the logarithm of nationwide search intensity in week $t$. Here, $t$ indicates the event week, which identifies weeks relative to March 1, 2020, when states began discussing the possibility of school closures. Before and After are indicators for week $t$ falling before or after March 1, 2020. Inclusion of week of year $w(t)$ (i.e., 1-52), and school year $y(t)$ (i.e., 20152020) fixed effects, which we call calendar effects, means that coefficients $\beta_{t}$ can be interpreted as differences in search intensity compared to the same weeks in prior years. The vector of weekly indicators covers all 52 weeks (other than that starting March 1, 2020 ) in the most recent year of our data, leaving the prior four years of data to identify week of year effects. Exclusion of the March 1, 2020 indicator, and inclusion of a PriorYears indicator for observations in the first four years of the data, means the coefficients $\beta_{t}$ can be interpreted as week t's deviation from calendar-predicted search intensity relative to March 1, 2020.

The nationwide before-after specification, which replaces the vector of weekly pre- and post-Covid indicators with a single post-Covid indicator, is

\footnotetext{
${ }^{7}$ Khan Academy is perhaps the most ambiguous search term, in that many schools use it to deliver curriculum to students, but parents and students can also access it without the school's involvement. We place it in the list of school-centered resources but often show separate results for it and for Google Classroom, the two most popular search terms in the post-Covid period.

${ }^{8}$ In seven cases ( 0.2 percent of counties), the county is within more than one DMA. In these cases, we include the county in both DMAs.

${ }^{9}$ See Table A.2 for these and other summary statistics.
} 
Table 1

Search intensity of Top 10 individual keywords.

\begin{tabular}{|c|c|c|c|c|c|}
\hline \multicolumn{3}{|c|}{ School-Centered Resources } & \multicolumn{3}{|c|}{ Parent-Centered Resources } \\
\hline Keyword & $\begin{array}{l}\text { Pre- } \\
\text { Covid }\end{array}$ & $\begin{array}{l}\text { Post- } \\
\text { Covid }\end{array}$ & Keyword & $\begin{array}{c}\text { Pre- } \\
\text { Covid }\end{array}$ & $\begin{array}{l}\text { Post- } \\
\text { Covid }\end{array}$ \\
\hline Google Classroom & 1.00 & 1.95 & Online school & 0.04 & 0.06 \\
\hline Khan Academy & 0.13 & 0.20 & Online classes & 0.03 & 0.05 \\
\hline Kahoot & 0.33 & 0.19 & Home school & 0.03 & 0.03 \\
\hline Seesaw & 0.02 & 0.15 & Online class & 0.00 & 0.02 \\
\hline Schoology & 0.07 & 0.12 & Math game & 0.03 & 0.02 \\
\hline Class Dojo & 0.01 & 0.06 & Distance learning & 0.00 & 0.02 \\
\hline Flipgrid & 0.00 & 0.05 & Math worksheets & 0.00 & 0.02 \\
\hline D2L & 0.05 & 0.05 & Online math & 0.00 & 0.01 \\
\hline Nearpod & 0.02 & 0.02 & Math problem & 0.00 & 0.01 \\
\hline Edmodo & 0.02 & 0.02 & Online reading & 0.00 & 0.00 \\
\hline
\end{tabular}

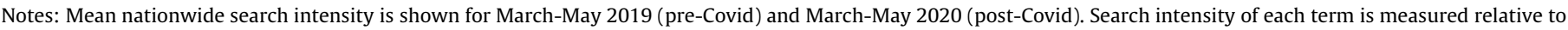
the pre-Covid search intensity for "Google Classroom". Searches are not case sensitive.

$\log \left(\right.$ SearchIntensity $\left._{t}\right)=\beta$ PostCovid $_{t}+\mu_{w(t)}+\lambda_{y(t)}+\varepsilon_{t}$.

Inclusion of calendar effects means $\beta$ can be interpreted as the overall post-Covid increase in search intensity compared to those same weeks in prior years. We exclude the ramp-up period of March 2020 from the before-after analysis because school closure discussions began in early March and nearly all schools were initially closed by states between March 16 and March $23 .{ }^{10}$ The post-Covid coefficient thus estimates the average increase in search intensity in April and May of 2020, when schools and parents were fully aware of the scope of educational disruption. The difference-in-difference estimator $\beta$ from Eq. (3) is the average of the April-May weekly event study coefficients $\beta_{4}$ through $\beta_{12}$ from Eq. (2).

To study how search intensity changed differentially by SES, we modify our nationwide specifications by interacting the pre- and post-Covid indicators with indicators for whether a DMA is of above or below median SES. Our modified event study specification is

$\log \left(\right.$ SearchIntensity $\left._{d t}\right)$

$=\sum_{t=-39}^{-1}\left(\beta_{t}\right.$ Before $_{t}+\gamma_{t}$ Before $_{t} *$ HighSES $\left._{d}\right)$

$+\sum_{t=1}^{12}\left(\beta_{t}\right.$ After $_{t}+\gamma_{t}$ After $_{t} *$ HighSES $\left._{d}\right)$

$+\alpha_{1}$ PriorYears $_{t}+\alpha_{2}$ PriorYears $_{t} *$ HighSES $_{d}+\mu_{w(t)}+\lambda_{y(t)}+\varepsilon_{t}$,

so that the coefficients $\gamma_{t}$ estimate the difference in weekly search intensity between high and low SES DMAs.

We modify the nationwide before-after specification to become a difference-in-difference of the form

$$
\begin{aligned}
\log _{\left(\text {SearchIntensity }_{d t}\right)} & =\beta_{1} \text { PostCovid }_{t} * \text { HighSES }_{d}+\beta_{2} \text { PostCovid }_{t} * \text { LowSES }_{d} \\
& +\sigma \text { HighSES }_{d}+\mu_{w(t)}+\lambda_{y(t)}+\varepsilon_{t} .
\end{aligned}
$$

Here, $\beta_{1}$ and $\beta_{2}$ measure the overall post-Covid change in search intensity for high and low SES DMAs respectively. We then compute the difference between those two coefficients, which corresponds to the average over time of the event study coefficients $\gamma_{4}$ through $\gamma_{12}$. We also run difference-in-difference specifications where the postCovid indicator is interacted with continuous measures of DMA characteristics, such as income, broadband penetration rates, and school rurality.

All DMA-level regressions use standard errors clustered by DMA and are weighted by DMA population to be nationally representative at the individual level. Nation-level regressions use

10 See Table A.3 for a list of school closure dates by state. heteroskedasticity robust standard errors. All regressions exclude weeks with the major school holidays of Thanksgiving, Christmas and New Year's. This has no effect on any estimates of interest but improves the scale of event-study graphs given the increased noise associated with such weeks.

\section{Results}

Nationwide search intensity for learning resources followed regular annual patterns until March 2020, at which point search intensity dramatically increased relative to similar months in prior years. As seen in Fig. 1, search intensity for school-centered resources typically peaks near the start of each school year and declines steadily until summer, when it largely vanishes. Search intensity for parent-centered resources is steadier throughout the school year but also declines substantially in summer. Covidrelated school closures altered these patterns, with nationwide search intensity for both types of learning resources roughly doubling by late March. ${ }^{11}$ Search intensity then starts to decay, likely due to households successfully locating their desired online resources and to school years ending in May and June. Accounting for usual calendar effects confirms all of these changes observed in the raw data, with no pre-trends prior to March 2020 and then a large and statistically significant rise in search intensity that then fades by late May. ${ }^{12}$

Growth in post-Covid search intensity varied substantially by geography and socioeconomic status. Fig. 2 maps DMAs by quartiles of SES (panel A) and post-Covid changes in search intensity (panel B), defined as April-May search intensity differences between 2020 and prior years. Areas with high income, parental education and technological access are concentrated in the Northeast and West coast, as well as Utah and Colorado. Post-Covid search intensity also increases most noticeably, though not exclusively, in the Northeast and West coast, suggesting that high SES areas see larger spikes in search intensity for learning resources.

Event study analyses show that weekly search intensity for learning resources increased significantly more in areas with higher income and better technological access. Fig. 3 shows Eq. (4)'s regression-based weekly difference in search intensity between DMAs above and below median SES, controlling for calendar effects. By mid-March, high SES areas see jumps in search intensity for both school- and parent-centered learning resources roughly 30 percent higher than low SES areas. These weekly differences are statistically significant and do not decay with time. Such

\footnotetext{
11 A logarithmic increase of 0.7 represents a roughly 100 percent increase $\left(e^{0.7}-1 \approx 1\right)$.

12 See Fig. A.1, based on Eq. (2).
} 


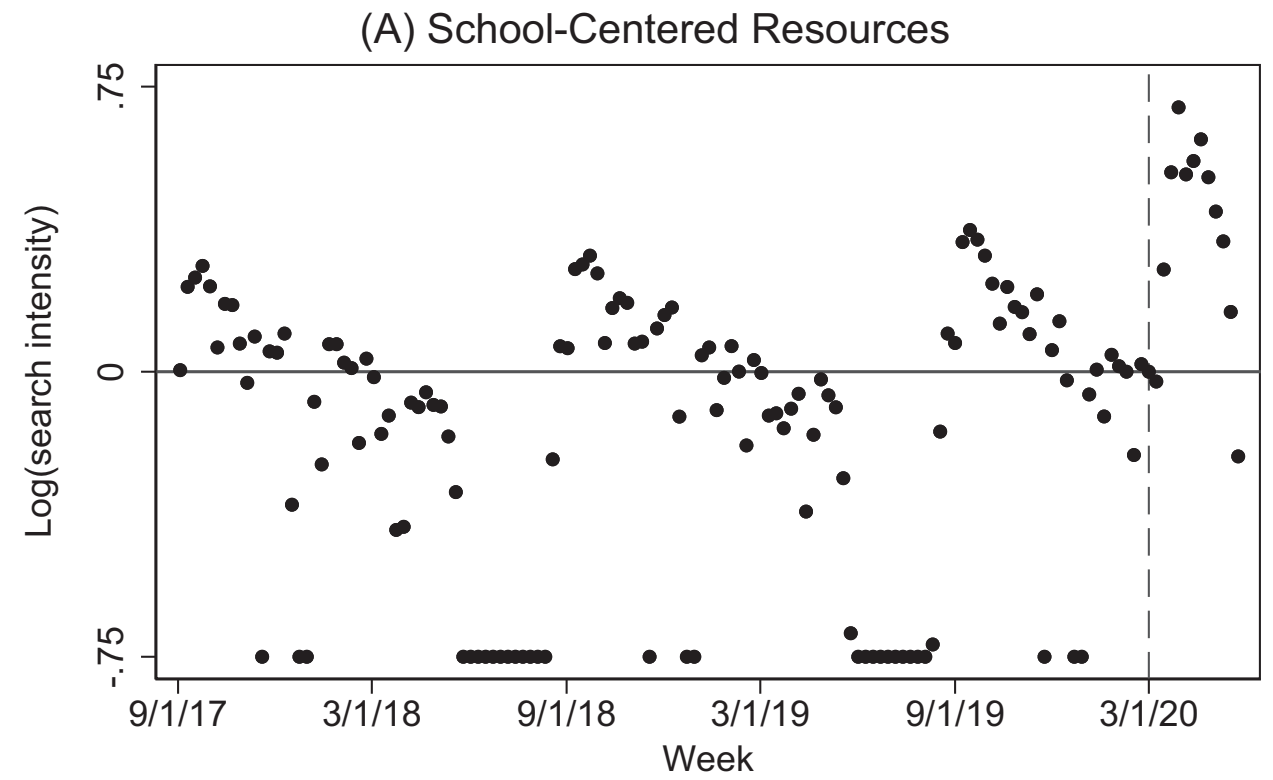

(B) Parent-Centered Resources

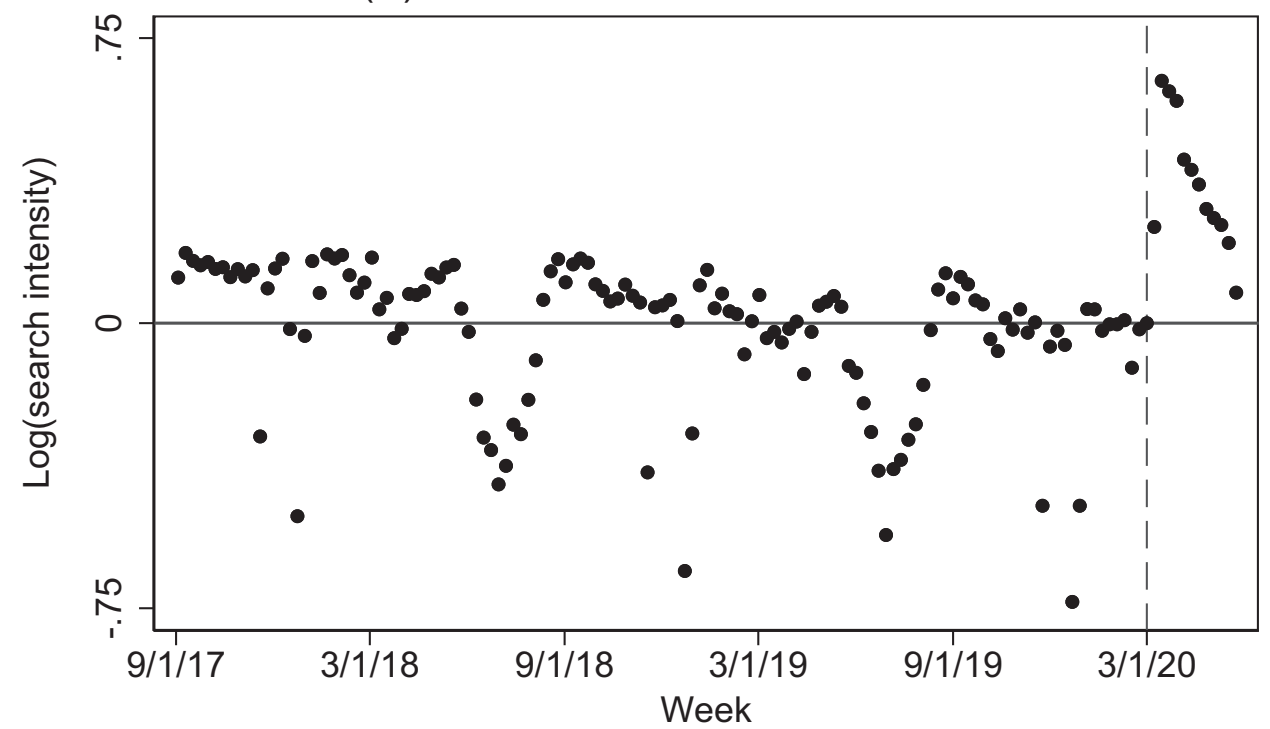

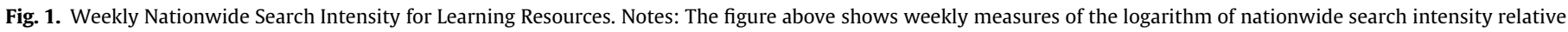

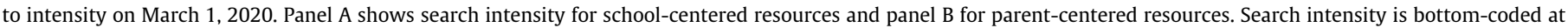
-0.75 for scaling purposes.

differences are also visible in the unadjusted data and when we fully interact the above and below median SES indicators with the calendar week and school year fixed effects. ${ }^{13}$

Difference-in-difference analyses show that the average postCovid increase in search intensity for learning resources was roughly twice as high in high SES areas as in low ones. Table 2 shows, in panel A's before-after analysis based on Eq. (3), that nationwide search intensity increased 67 percent (51 log points) for school-based resources, driven largely by a 114 percent (76 log point) increase for Google Classroom, and 40 percent (34 log points) for parent-centered resources. Panel B, based on Eq. (5),

\footnotetext{
13 See Fig. A.2 for evidence from the unadjusted data. See also Fig. A.3, which replicates Fig. 3 but fully interacts all calendar week and school year fixed effects with above and below median SES indicators.
}

shows that search intensity for all of these resources increased substantially in low SES areas but much more so in high SES areas. Low SES areas searched 36 percent (31 log points) more intensely for school-centered resources but high SES areas searched an additional 48 percent ( $39 \log$ points) more intensely, a difference that is highly statistically significant. Search intensity for parent-centered resources increased by 25 percent (22 log points) in low SES areas but by an additional 27 percent ( $24 \log$ points) in high SES areas. ${ }^{14}$ These patterns hold for broad resource categories and for individual products like Google Classroom and Khan Academy. Interestingly,

\footnotetext{
14 Table A.8 shows similar results when replicating Table 2 fully interacting all calendar week and school year fixed effects with above and below median SES indicators.
} 


\section{(A) Socioeconomic Status}

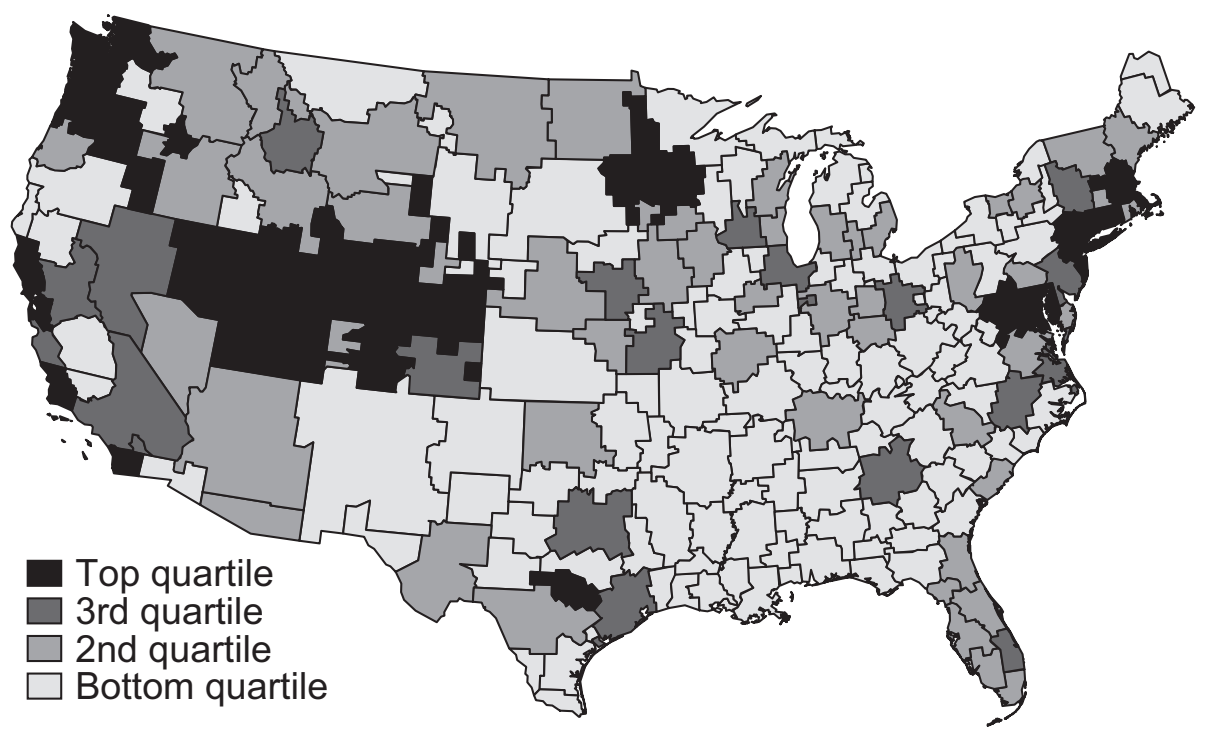

(B) Post-Covid Change in Search Intensity

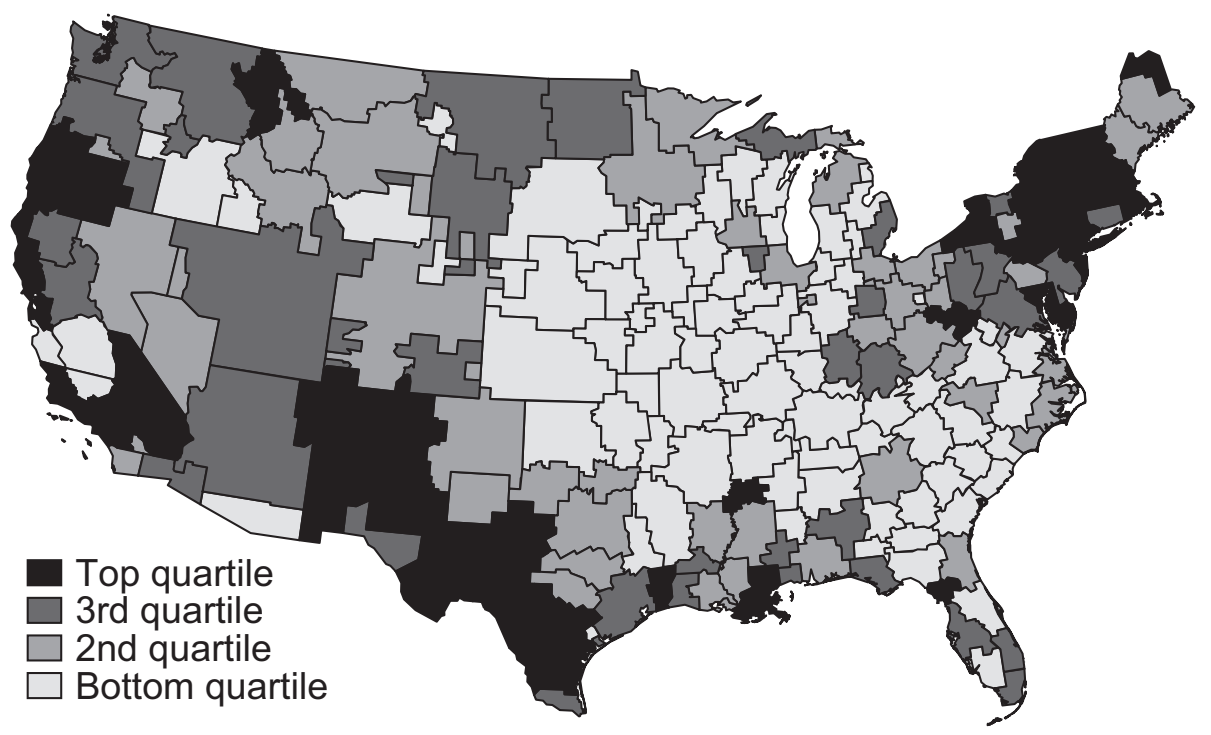

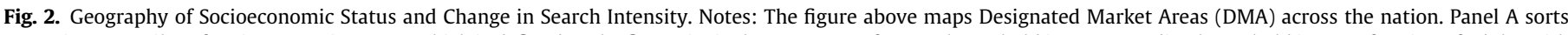

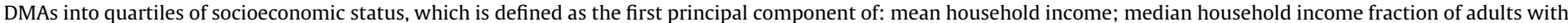

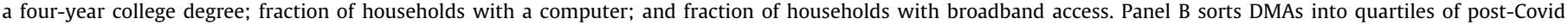

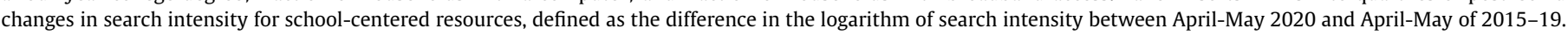

the high SES indicator in panel B's regressions suggests few clear differences by SES in search intensity prior to the pandemic.

The pandemic widened gaps in search intensity for learning resources not only by broad measures of SES, but also by specific measures such as income, technological access, rurality and race. Panel C of Table 2 shows difference-in-difference analyses where continuous DMA-level demographic measures have been interacted with a post-Covid indicator. Search intensity for schoolcentered resources increases by an additional 15 percent (14 log points) with every additional $\$ 10,000$ in mean household income and by a roughly additional $4-5$ percent ( 3.6 and 4.4 log points) with every percentage point increase in the fraction of households with broadband internet and a computer. A percentage point increase in technological access is equivalent to approximately a quarter of a standard deviation. A 10 percentage point increase in the fraction of schools located in rural areas (nearly half a standard deviation) is associated with a 17 percent (16 log point) lower change in search intensity, while a 10 percentage point (two-thirds of a standard deviation) increase in the fraction of students who are Black is associated with a nine percent lower change in search intensity. Parent-based resources show similar patterns, though with somewhat smaller magnitudes. Measures of SES (such as income or broadband access), school rurality and race are independently associated with search behavior even when controlling for each other. ${ }^{15}$

Finally, we note four additional analyses that further illuminate or strengthen the prior results. First, Table A.5 presents effects by 
(A) School-Centered Resources

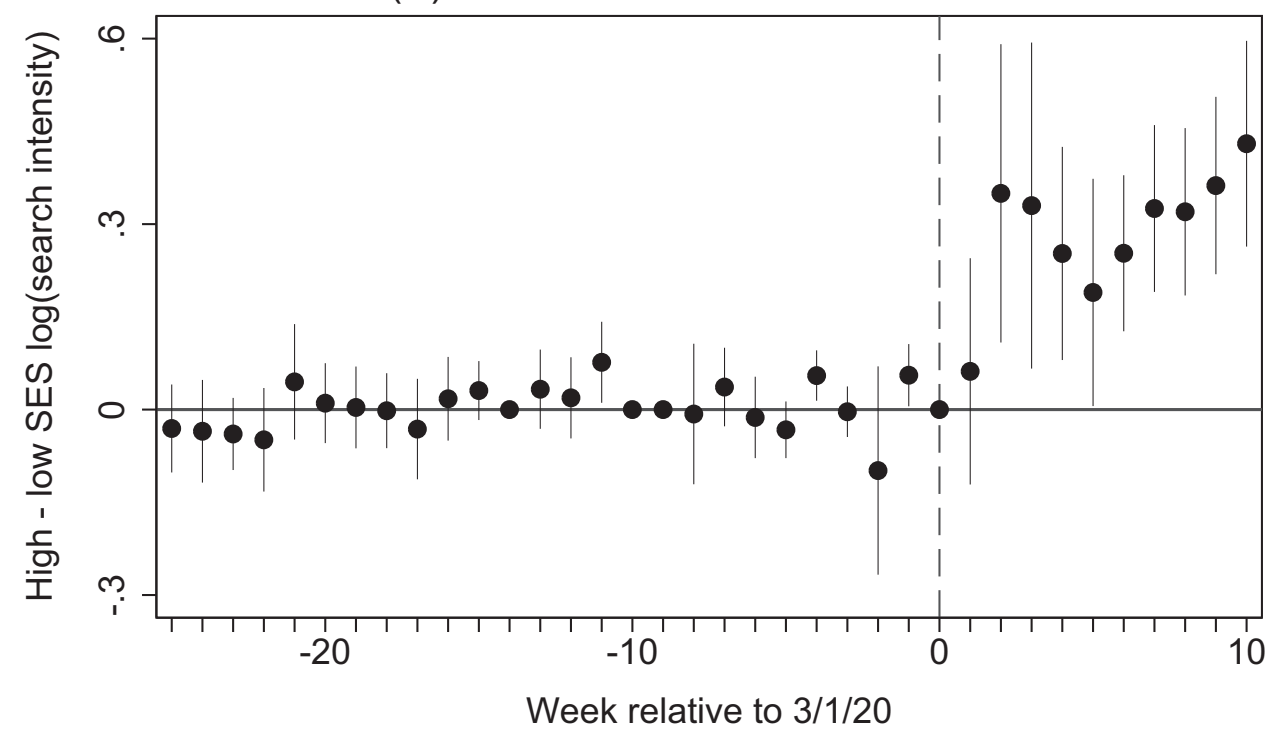

(B) Parent-Centered Resources

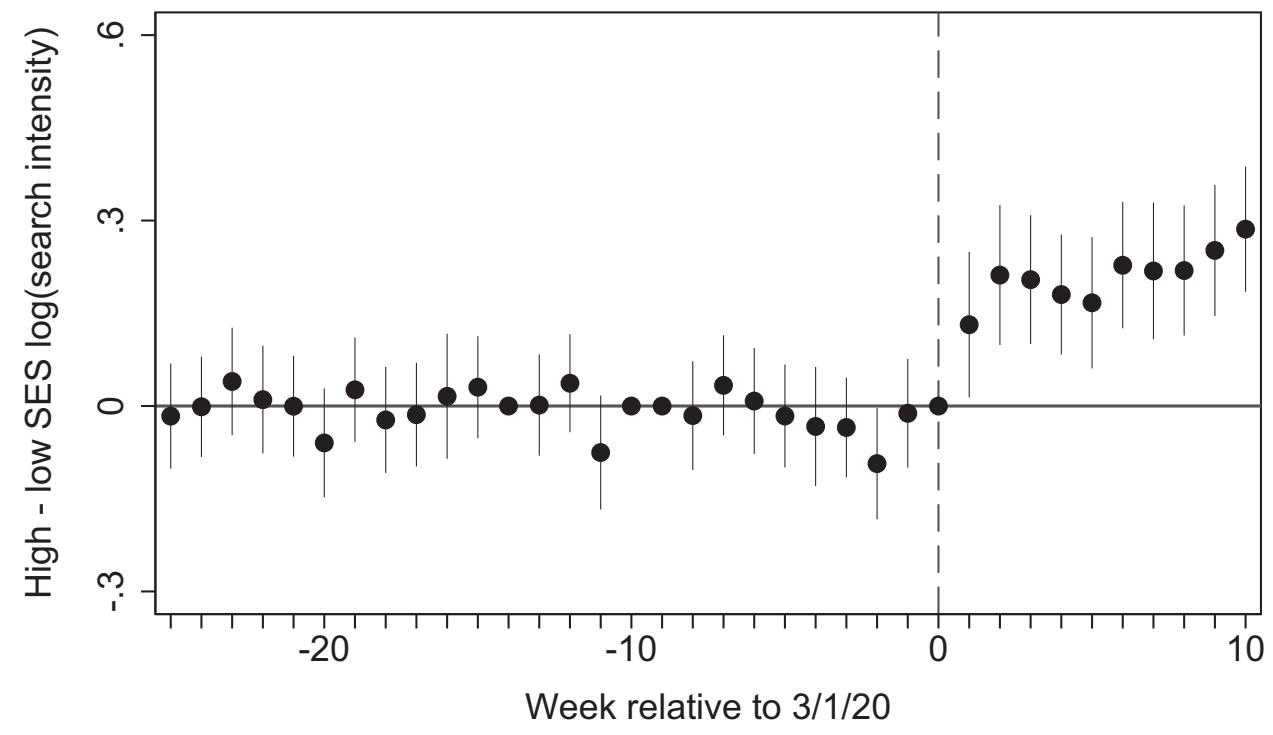

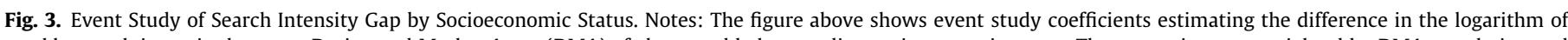

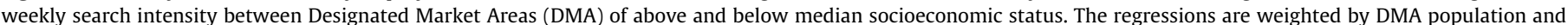

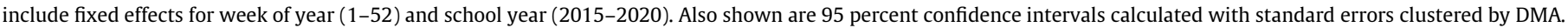

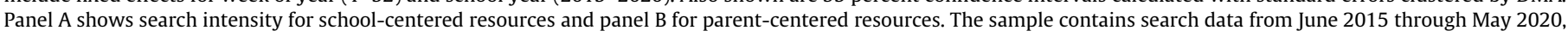
excluding weeks with major school holidays.

SES quartile. This analysis shows that the observed post-Covid widening of search intensity gaps is fairly linear in SES and not just driven by the most and least disadvantaged areas. Second, the widening of gaps by SES is not only the result of SES gaps between regions of the country but gaps within regions. Table A.6 reports effects for each of the four U.S. Census regions (Northeast, Midwest, South, West) and shows that SES-based search intensity gaps appear even when making within-region comparisons. Finally, because search intensity is coded as zero for terms with low search volume in a given DMA-week, Table A.7 excludes DMAs with low search volume. The results are unchanged, which is unsurprising given that such areas tend to have low population.

Fourth, we show that changes in search intensity for educational resources are correlated with changes in actual math pro- gress made by students, suggesting a relationship between online search and actual student and parent behaviors that impact educational outcomes. Fig. A.4 plots the DMA-level relationship between post-Covid changes in math progress, as measured by badges earned in the popular math app Zearn, and post-Covid changes in search intensity for school- and parentcentered resources. For both types of search, we observe a high correlation ( 0.70 and 0.55$)$ between changes in search behavior and changes in math progress. Areas where households began searching much more for educational resources are also those where students made the most progress in math. This makes more plausible the idea that online search metrics serve as useful proxies for households' educational behaviors and investments. 
Table 2

Changes in search intensity by socioeconomic status and other measures.

\begin{tabular}{|c|c|c|c|c|}
\hline & $\begin{array}{l}\text { School- } \\
\text { centered } \\
\text { resources } \\
(1)\end{array}$ & $\begin{array}{l}\text { Parent- } \\
\text { centered } \\
\text { resources } \\
\quad(2)\end{array}$ & $\begin{array}{c}\text { Google } \\
\text { Classroom } \\
(3)\end{array}$ & $\begin{array}{c}\text { Khan } \\
\text { Academy } \\
(4)\end{array}$ \\
\hline $\begin{array}{l}\text { (A) Nationwide } \\
\text { Post-Covid }\end{array}$ & $\begin{array}{l}0.51^{* * *} \\
(0.05)\end{array}$ & $\begin{array}{l}0.34^{* * *} \\
(0.02)\end{array}$ & $\begin{array}{l}0.76^{* * *} \\
(0.05)\end{array}$ & $\begin{array}{l}0.41^{* * *} \\
(0.03)\end{array}$ \\
\hline \multicolumn{5}{|l|}{ (B) By median SES } \\
\hline Post-Covid $*$ High SES & $\begin{array}{l}0.70^{* * * *} \\
(0.08)\end{array}$ & $\begin{array}{l}0.46^{* * *} \\
(0.03)\end{array}$ & $\begin{array}{l}0.92^{* * *} \\
(0.08)\end{array}$ & $\begin{array}{l}0.50^{* * *} \\
(0.05)\end{array}$ \\
\hline Post-Covid $*$ Low SES & $\begin{array}{l}0.31^{* * *} \\
(0.05)\end{array}$ & $\begin{array}{l}0.22^{* * *} \\
(0.02)\end{array}$ & $\begin{array}{l}0.59^{* * *} \\
(0.07)\end{array}$ & $\begin{array}{l}0.32^{* * *} \\
(0.03)\end{array}$ \\
\hline High SES & $\begin{array}{c}0.02 \\
(0.06)\end{array}$ & $\begin{array}{c}0.01 \\
(0.05)\end{array}$ & $\begin{array}{c}0.10 \\
(0.10)\end{array}$ & $\begin{array}{c}0.05 \\
(0.05)\end{array}$ \\
\hline High-Low SES Change & $\begin{array}{l}0.39^{* * *} \\
(0.11)\end{array}$ & $\begin{array}{l}0.24^{* * *} \\
(0.03)\end{array}$ & $\begin{array}{l}0.33^{* * *} \\
(0.11)\end{array}$ & $\begin{array}{l}0.19^{* * *} \\
(0.05)\end{array}$ \\
\hline $\begin{array}{l}\text { (C) By income, online access, race } \\
\text { Post-Covid } * \text { Household income }\end{array}$ & $\begin{array}{l}0.14^{* * *} \\
(0.04)\end{array}$ & $\begin{array}{l}0.08^{* * *} \\
(0.01)\end{array}$ & $\begin{array}{l}0.12^{* * *} \\
(0.03)\end{array}$ & $\begin{array}{l}0.07^{* * *} \\
(0.02)\end{array}$ \\
\hline Post-Covid $*$ Broadband penetration rate & $\begin{array}{l}0.36^{* * *} \\
(0.08)\end{array}$ & $\begin{array}{l}0.30^{* * * *} \\
(0.03)\end{array}$ & $\begin{array}{c}0.31^{* * *} \\
(0.09)\end{array}$ & $\begin{array}{c}0.27^{* * *} \\
(0.04)\end{array}$ \\
\hline Post-Covid $*$ Computer penetration rate & $\begin{array}{c}0.44^{* * *} \\
(0.10)\end{array}$ & $\begin{array}{c}0.41^{* * * *} \\
(0.04)\end{array}$ & $\begin{array}{c}0.41^{* * *} \\
(0.10)\end{array}$ & $\begin{array}{l}0.33^{* * *} \\
(0.07)\end{array}$ \\
\hline Post-Covid $*$ Fraction of schools in rural areas & $\begin{array}{c}-0.16^{* * *} \\
(0.03)\end{array}$ & $\begin{array}{c}-0.08^{* * *} \\
(0.01)\end{array}$ & $\begin{array}{c}-0.18^{* * *} \\
(0.03)\end{array}$ & $\begin{array}{c}-0.09^{* * *} \\
(0.02)\end{array}$ \\
\hline Post-Covid $*$ Fraction of students who are Black & $\begin{array}{c}-0.09^{* * *} \\
(0.03)\end{array}$ & $\begin{array}{c}-0.06^{* * *} \\
(0.01)\end{array}$ & $\begin{array}{l}-0.03 \\
(0.04)\end{array}$ & $\begin{array}{c}-0.06^{* * *} \\
(0.02)\end{array}$ \\
\hline $\mathrm{N}$ & 50,400 & 50,400 & 50,400 & 50,400 \\
\hline
\end{tabular}

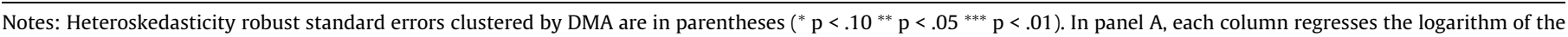

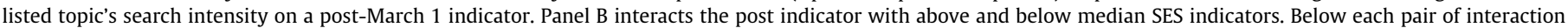

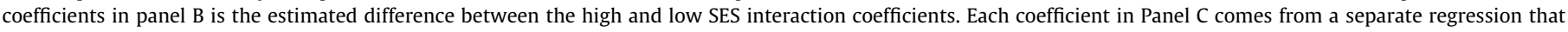

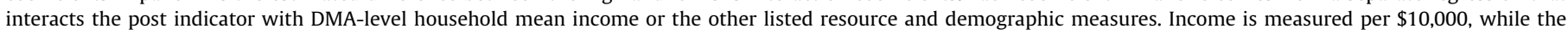

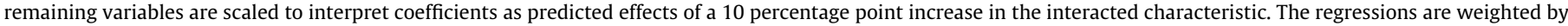

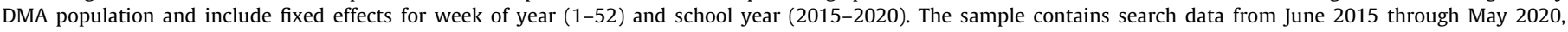
excluding March 2020 and weeks with major school holidays.

\section{Discussion}

We document a sharp increase in searches for learning resources as schools closed in response to the Covid-19 pandemic. By April 2020, nationwide search intensity for online learning resources had roughly doubled relative to baseline. The shock of school closures increased demand both for the specific online platforms schools shifted instruction to (such as Google Classroom) and for the supplemental resources that households sought out to fill gaps in their learning (such as math worksheets). The likelihood of future school closures or partial reopenings implies these supplemental online resources are likely to become important drivers of student learning.

Though demand for online resources increased in both high and low SES areas, the increase was substantially larger in high SES areas. Areas of the country with higher income, greater internet access, and fewer rural schools had substantially larger increases than less advantaged areas. Along with results from several contemporaneous studies, these results suggest that academic gaps across students will be wider than normal in future school years, a result strengthened by our finding that changes in search behavior correlate with changes in students' math progress.

Our results suggest the potential value of policy responses that directly address these documented inequalities in engagement with online learning resources. Students in low SES areas and rural communities are likely to need additional support to overcome the educational challenges created by Covid-19. Because online learning will likely remain a key component of school systems in the near future, school leaders and policymakers may want to priori- tize access to home computers and broadband internet. Improving access to and engagement with online learning platforms will likely be an important step to equalizing learning opportunities and preventing a widening of achievement gaps.

Publicly available, high frequency internet search data helps illuminate the evolution of educational choices made by households, as well as socioeconomic inequalities in those choices. Our analyses can be updated in real time to study future changes in engagement with online learning, can be modified to study different search terms, and can be replicated in other countries. Household adaptation to schooling shocks is an understudied phenomenon that can be readily observed in internet search data. Understanding and accounting for such adaptive responses by parents and students will be critical to predicting the long-term effects of the pandemic, as well as understanding broader educational phenomena.

\section{Declaration of Competing Interest}

The authors declare that they have no known competing financial interests or personal relationships that could have appeared to influence the work reported in this paper.

\section{Appendix A}

See Figs. A.1-A.4.

See Tables A.1-A.8. 


\section{(A) School-Centered Resources}

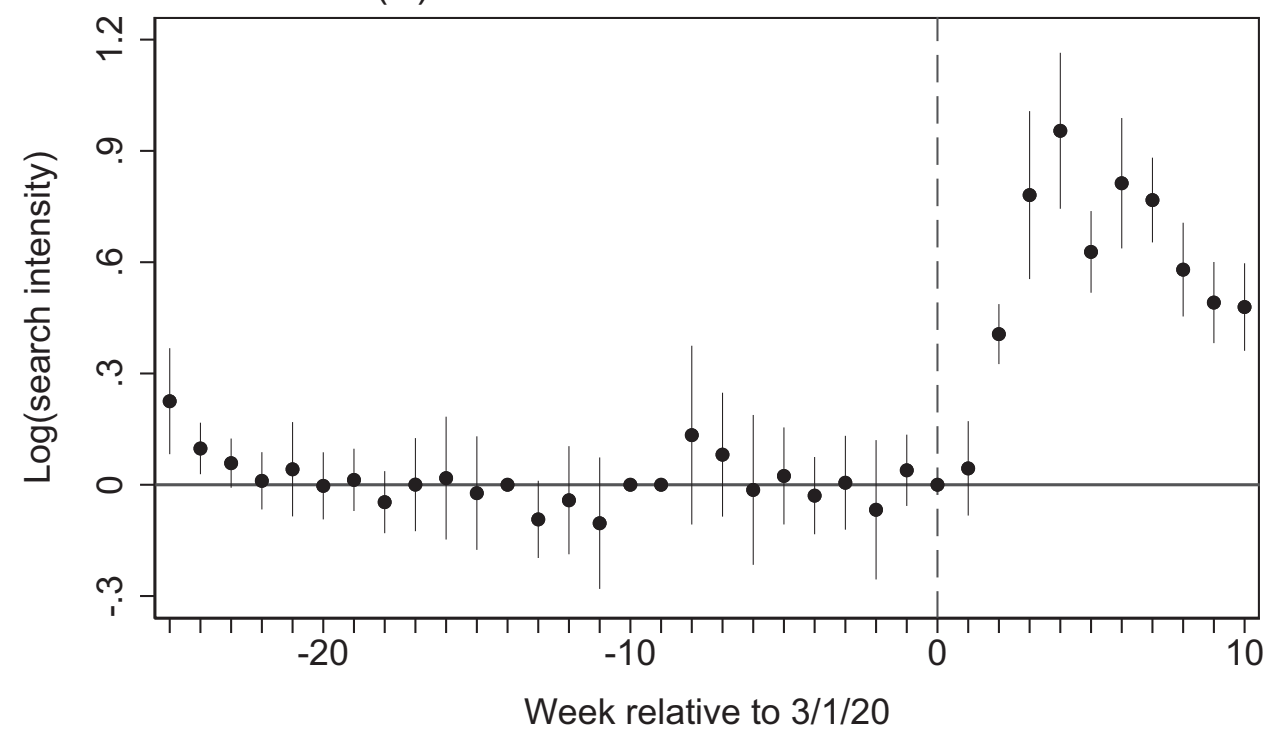

(B) Parent-Centered Resources

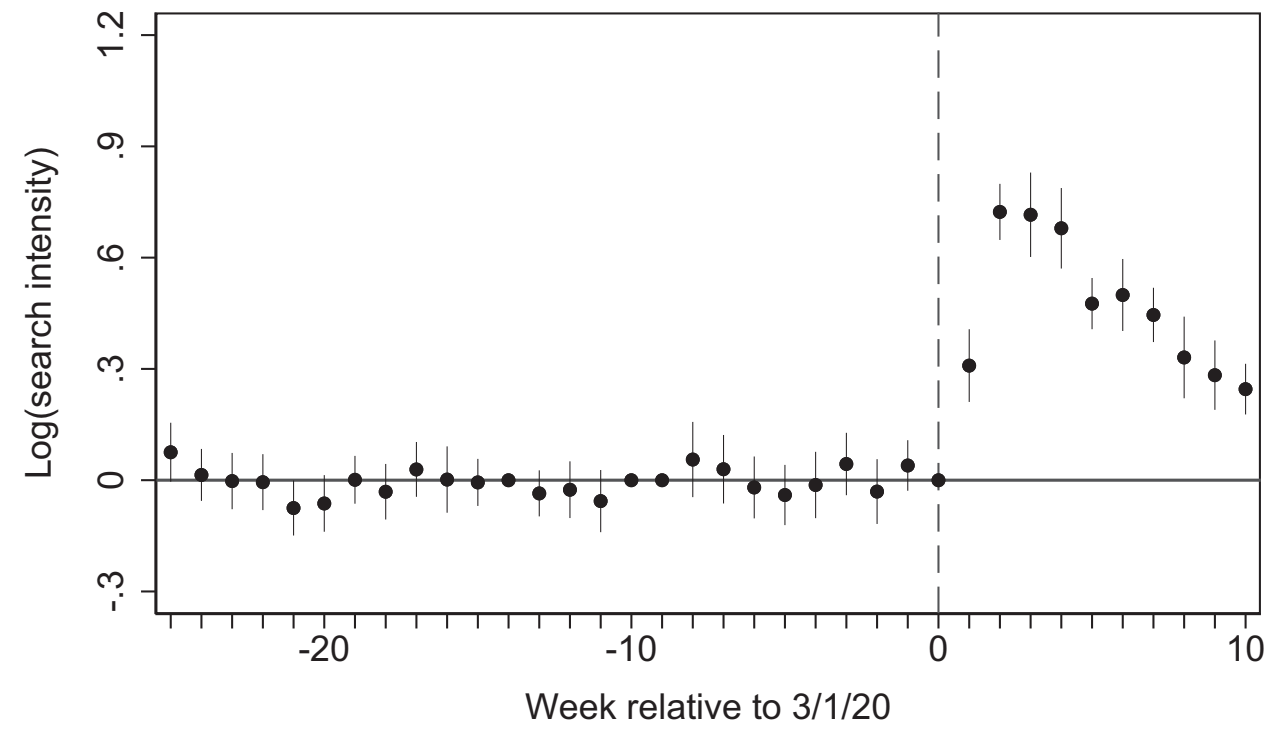

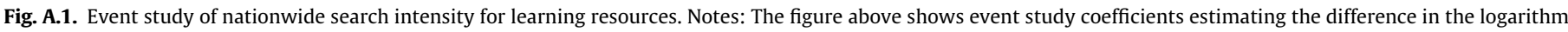

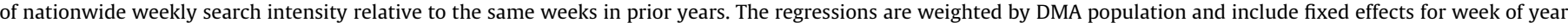

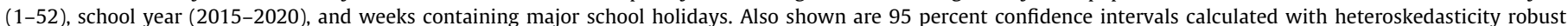

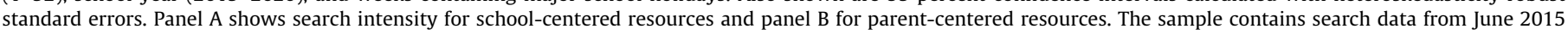
through May 2020, excluding weeks with major school holidays. 
(A) School-Centered Resources

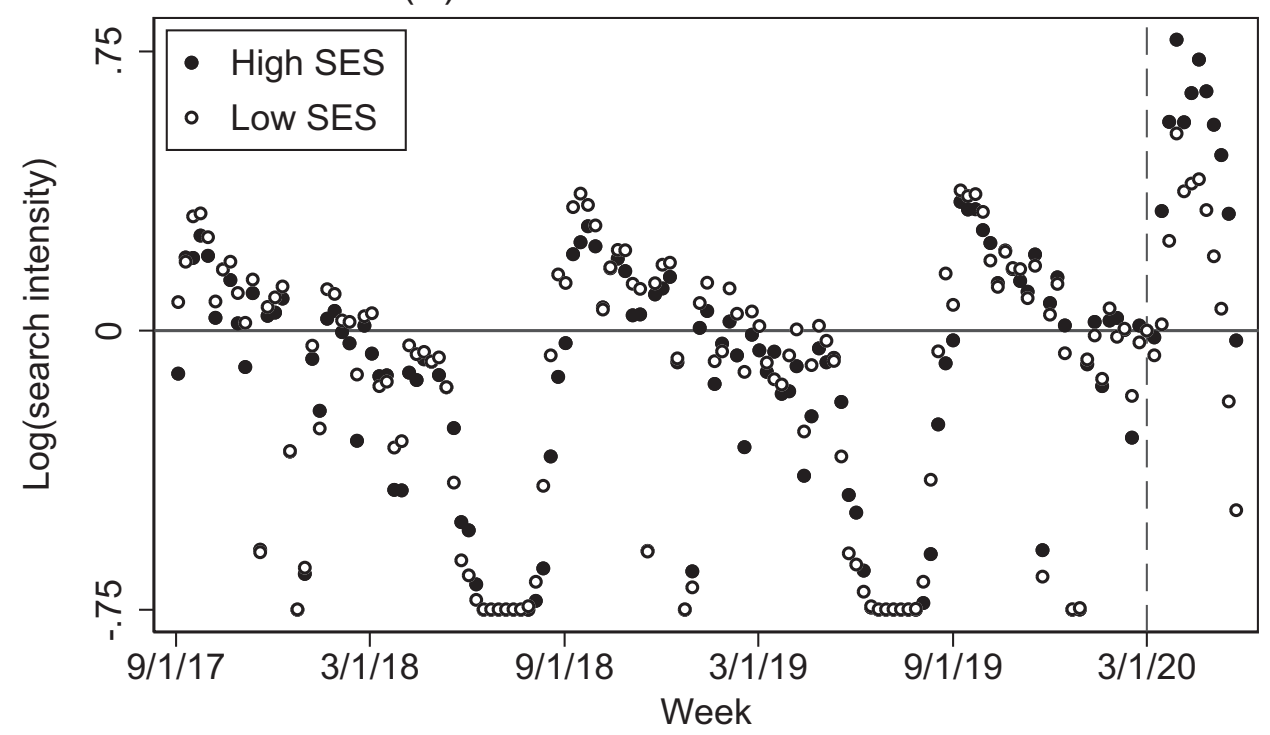

(B) Parent-Centered Resources

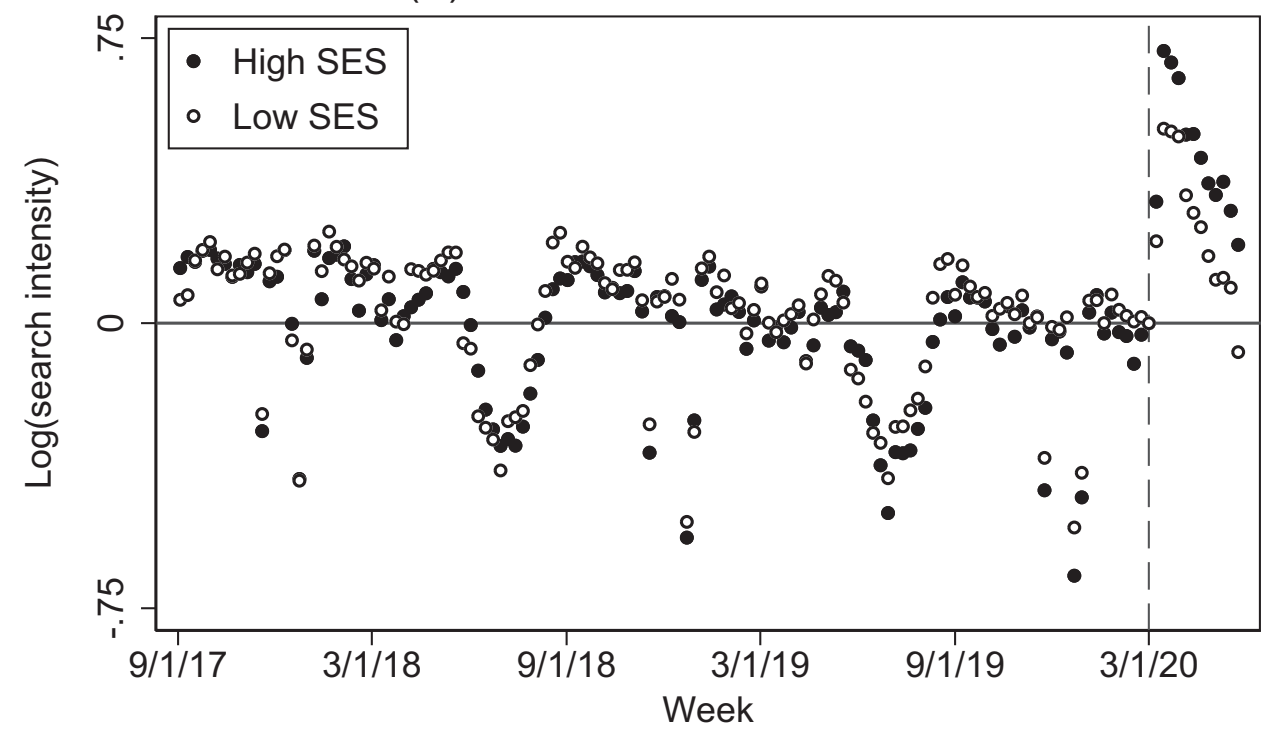

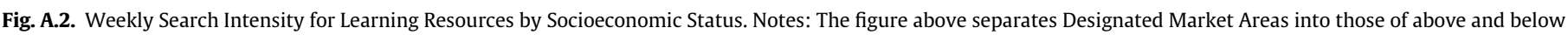

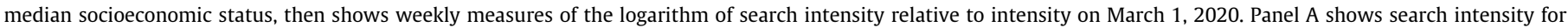
school-centered resources and panel B for parent-centered resources. Search intensity is bottom-coded at -0.75 for scaling purposes. 
(A) School-Centered Resources

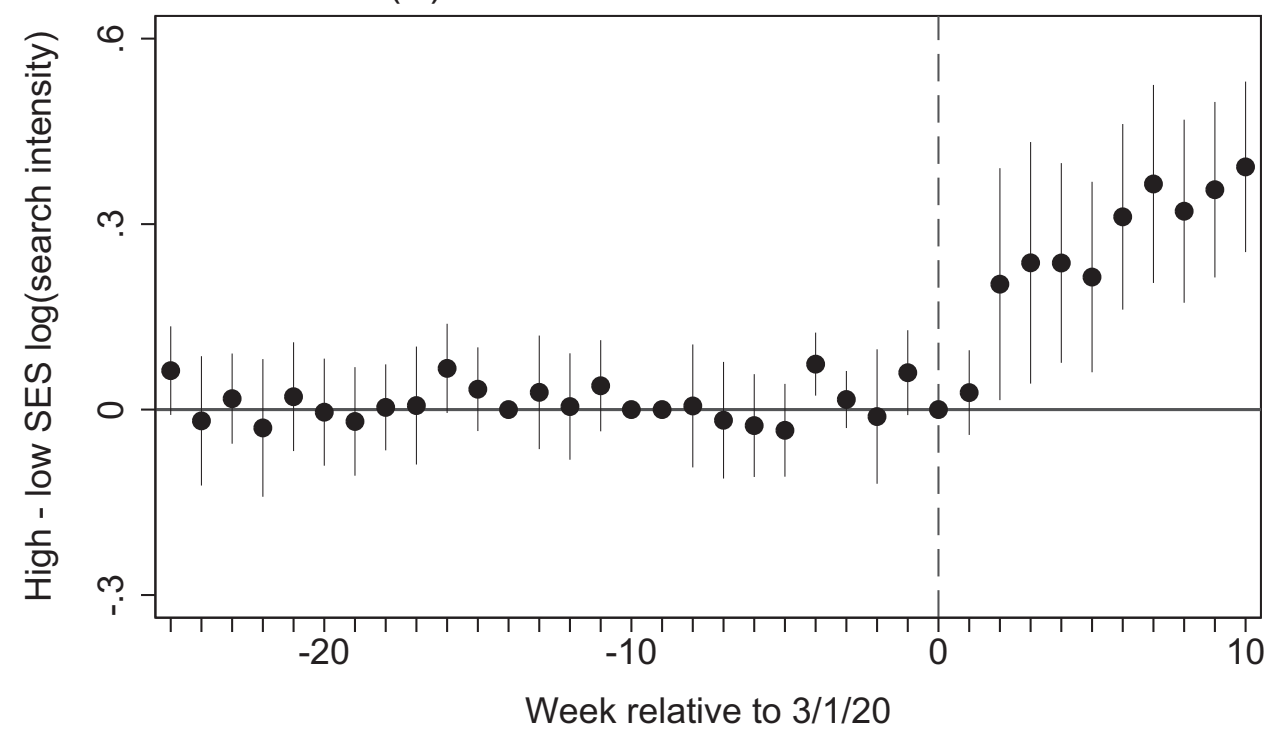

(B) Parent-Centered Resources

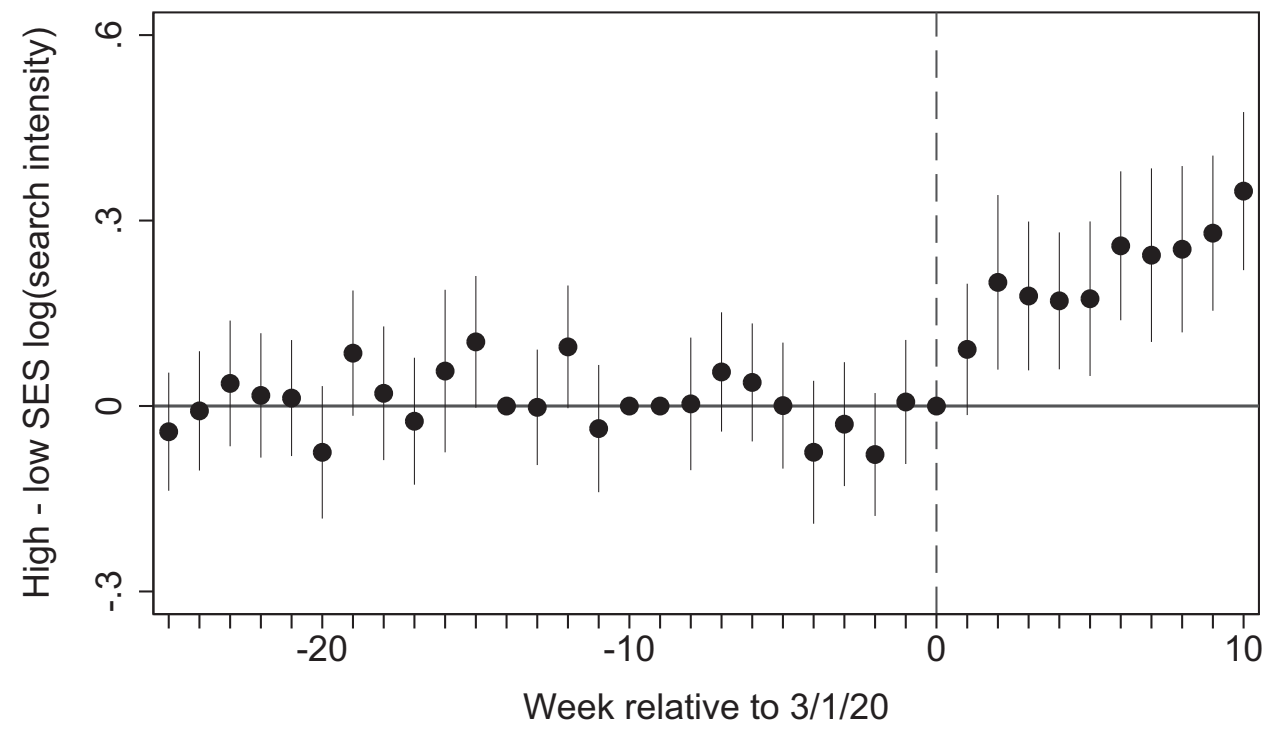

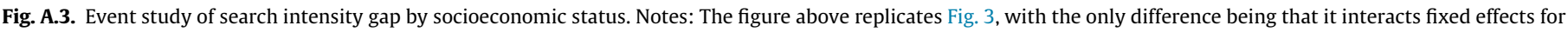

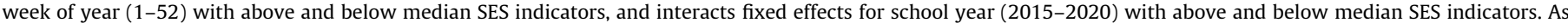

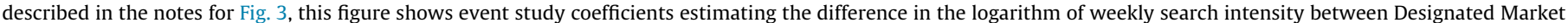

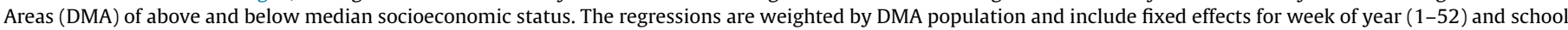

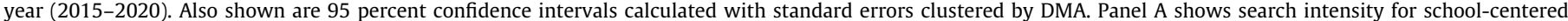
resources and panel B for parent-centered resources. The sample contains search data from June 2015 through May 2020 , excluding weeks with major school holidays. 


\section{(A) School-Centered Resources}

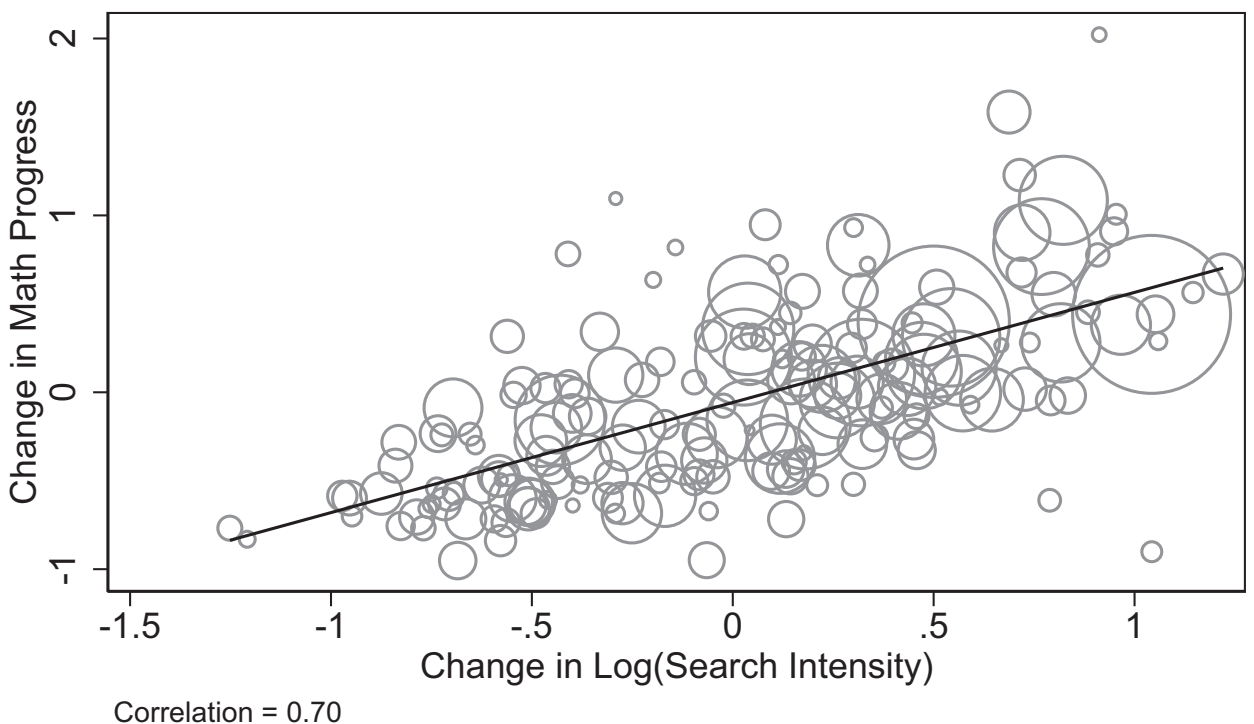

(B) Parent-Centered Resources

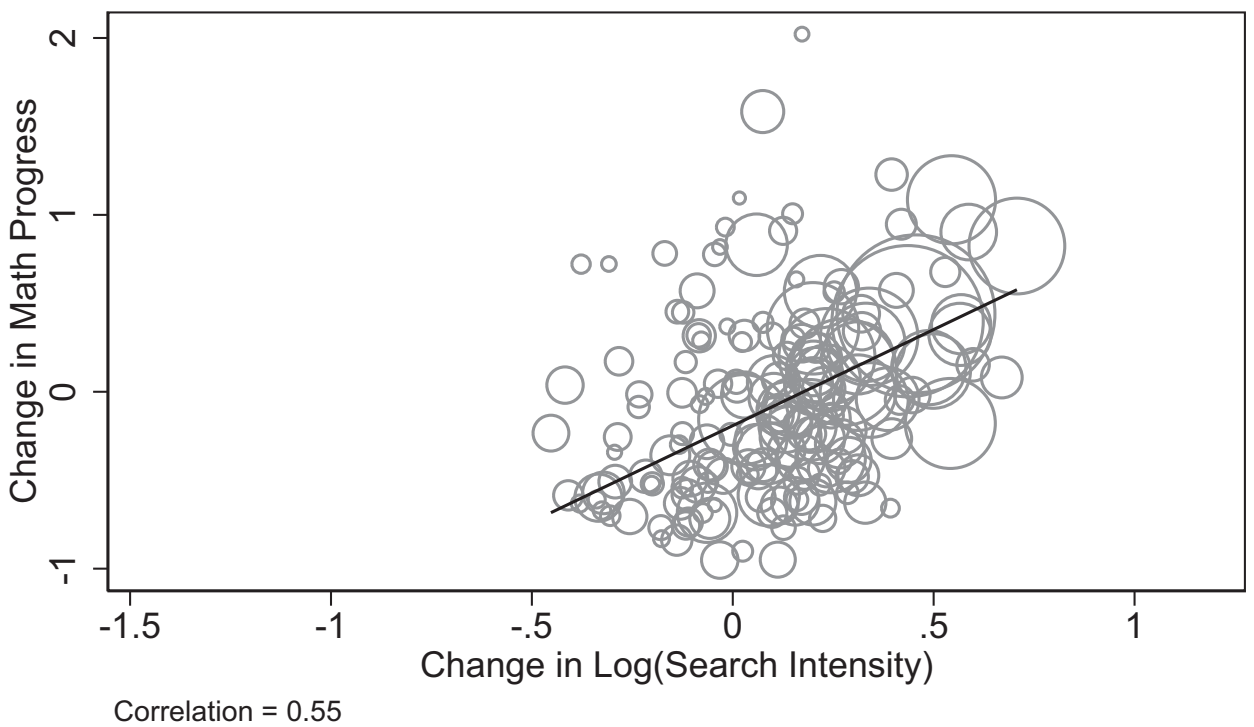

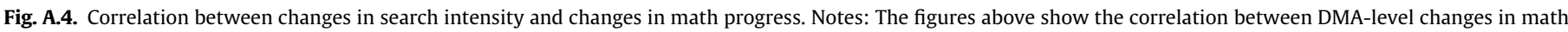

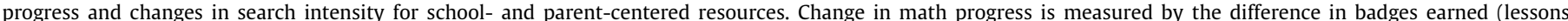

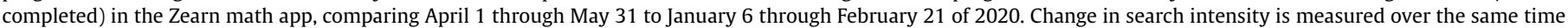

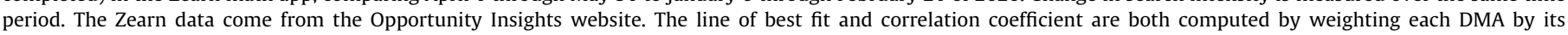
population. 
Table A.1

Search intensity of individual keywords.

\begin{tabular}{|c|c|c|c|c|c|}
\hline \multicolumn{3}{|c|}{ Branded Learning Resources } & \multicolumn{3}{|c|}{ General Learning Resources } \\
\hline Keyword & $\begin{array}{l}\text { Pre- } \\
\text { Covid }\end{array}$ & $\begin{array}{l}\text { Post- } \\
\text { Covid }\end{array}$ & Keyword & $\begin{array}{l}\text { Pre- } \\
\text { Covid }\end{array}$ & $\begin{array}{l}\text { Post- } \\
\text { Covid }\end{array}$ \\
\hline Google Classroom & 1.00 & 1.95 & Online school & 0.04 & 0.06 \\
\hline Khan Academy & 0.13 & 0.20 & Online classes & 0.03 & 0.05 \\
\hline Kahoot & 0.33 & 0.19 & Home school & 0.03 & 0.03 \\
\hline Seesaw & 0.02 & 0.15 & Online class & 0.00 & 0.02 \\
\hline Schoology & 0.07 & 0.12 & Math game & 0.03 & 0.02 \\
\hline Class Dojo & 0.01 & 0.06 & Distance learning & 0.00 & 0.02 \\
\hline Flipgrid & 0.00 & 0.05 & Math worksheets & 0.00 & 0.02 \\
\hline D2L & 0.05 & 0.05 & Online math & 0.00 & 0.01 \\
\hline Nearpod & 0.02 & 0.02 & Math problem & 0.00 & 0.01 \\
\hline Edmodo & 0.02 & 0.02 & Online reading & 0.00 & 0.00 \\
\hline Flocabulary & 0.02 & 0.02 & Educational game & 0.00 & 0.00 \\
\hline Starfall & 0.03 & 0.02 & Education game & 0.00 & 0.00 \\
\hline GoNoodle & 0.00 & 0.02 & Online lessons & 0.00 & 0.00 \\
\hline ClassDojo & 0.00 & 0.02 & Free preschool worksheets & 0.00 & 0.00 \\
\hline \multirow[t]{17}{*}{ Socrative } & 0.02 & 0.00 & Educational apps & 0.00 & 0.00 \\
\hline & & & Education apps & 0.00 & 0.00 \\
\hline & & & Educational games & 0.00 & 0.00 \\
\hline & & & Vocabulary game & 0.00 & 0.00 \\
\hline & & & School worksheets & 0.00 & 0.00 \\
\hline & & & Reading game & 0.00 & 0.00 \\
\hline & & & Online tutoring & 0.00 & 0.00 \\
\hline & & & Virtual education & 0.00 & 0.00 \\
\hline & & & Online lesson & 0.00 & 0.00 \\
\hline & & & Virtual school & 0.00 & 0.00 \\
\hline & & & Educational videos & 0.00 & 0.00 \\
\hline & & & Educational app & 0.00 & 0.00 \\
\hline & & & Free school worksheets & 0.00 & 0.00 \\
\hline & & & Education app & 0.00 & 0.00 \\
\hline & & & Online science & 0.00 & 0.00 \\
\hline & & & Online social studies & 0.00 & 0.00 \\
\hline & & & Education games & 0.00 & 0.00 \\
\hline
\end{tabular}

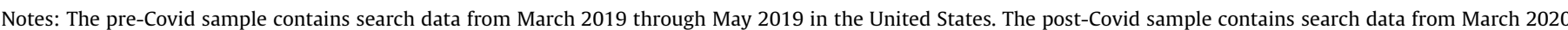

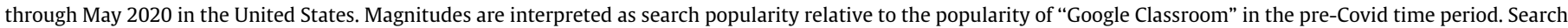

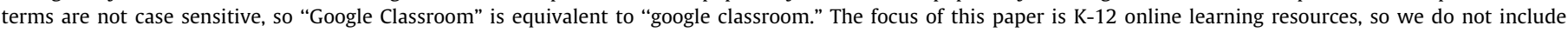
keywords related to professional services (e.g., Webex), textbooks (e.g., Pearson), or postsecondary (e.g., Canvas), or adult learning (e.g., Masterclass).

Table A.2

Summary statistics of DMAs.

\begin{tabular}{|c|c|c|}
\hline & Mean & SD \\
\hline \multicolumn{3}{|l|}{ (A) 2016 American Community Survey } \\
\hline Mean household income $(1,000 s)$ & 73.36 & 12.92 \\
\hline Median household income $(1,000 \mathrm{~s})$ & 54.89 & 10.20 \\
\hline Fraction of adults with a B.A. & 26.74 & 6.46 \\
\hline Fraction of households with broadband internet & 77.22 & 5.46 \\
\hline $\begin{array}{l}\text { Fraction of households with a computer } \\
\text { (B) } 2016 \text { Stanford Education Data Archive }\end{array}$ & 86.74 & 3.84 \\
\hline Fraction of schools in rural areas & 0.25 & 0.17 \\
\hline Fraction of students who are Black & 0.14 & 0.15 \\
\hline $\mathrm{N}$ & 210 & \\
\hline
\end{tabular}

Notes: Panel A presents summary statistics of data from the 2016 American Community Survey (ACS). We use county-level ACS data and generate DMA-level measures as the population-weighted average across the counties within each DMA. Panel B presents summary statistics of 2016 data from the Stanford Education Data Archive (SEDA). We again use county-level SEDA data and generate DMA-level measures as the population-weighted average. 
Table A.3

School closure dates by state.

\begin{tabular}{|c|c|c|c|c|}
\hline State & $\begin{array}{l}\text { Legal } \\
\text { status }\end{array}$ & $\begin{array}{l}\text { State closure } \\
\text { start date }\end{array}$ & $\begin{array}{l}\text { Date closed } \\
\text { for the year }\end{array}$ & $\begin{array}{c}\text { Public school } \\
\text { enrollment }\end{array}$ \\
\hline Alabama & Ordered & March 19 & April 6 & 744,930 \\
\hline Alaska & Ordered & March 16 & April 9 & 132,737 \\
\hline Arizona & Ordered & March 16 & March 30 & $1,123,137$ \\
\hline Arkansas & Ordered & March 17 & April 6 & 493,447 \\
\hline California & Recommended & March 19 & April 1 & $6,309,138$ \\
\hline Colorado & Ordered & March 23 & April 20 & 905,019 \\
\hline Connecticut & Ordered & March 17 & May 5 & 535,118 \\
\hline Delaware & Ordered & March 16 & April 24 & 136,264 \\
\hline District of Columbia & Ordered & March 16 & April 17 & 85,850 \\
\hline Florida & Recommended & March 16 & April 18 & $2,816,791$ \\
\hline Georgia & Ordered & March 18 & April 1 & $1,764,346$ \\
\hline Hawaii & Ordered & March 23 & April 17 & 181,550 \\
\hline Idaho & Recommended & March 24 & April 6 & 297,200 \\
\hline Illinois & Ordered & March 17 & April 17 & $2,026,718$ \\
\hline Indiana & Ordered & March 20 & April 2 & $1,049,547$ \\
\hline Iowa & Ordered & March 16 & April 17 & 509,831 \\
\hline Kansas & Ordered & March 18 & March 17 & 494,347 \\
\hline Kentucky & Recommended & March 16 & April 20 & 684,017 \\
\hline Louisiana & Ordered & March 16 & April 15 & 716,293 \\
\hline Maine & Recommended & March 16 & March 31 & 180,512 \\
\hline Maryland & Ordered & March 16 & May 6 & 886,221 \\
\hline Massachusetts & Ordered & March 17 & April 21 & 964,514 \\
\hline Michigan & Ordered & March 16 & April 2 & $1,528,666$ \\
\hline Minnesota & Ordered & March 18 & April 23 & 875,021 \\
\hline Mississippi & Ordered & March 20 & April 14 & 483,150 \\
\hline Missouri & Ordered & March 23 & April 9 & 915,040 \\
\hline Montana & Closure expired & March 16 & $\mathrm{n} / \mathrm{a}$ & 146,375 \\
\hline Nebraska & Ordered & March 23 & April 3 & 319,194 \\
\hline Nevada & Ordered & March 16 & April 21 & 473,744 \\
\hline New Hampshire & Ordered & March 16 & April 16 & 180,888 \\
\hline New Jersey & Ordered & March 18 & May 4 & $1,410,421$ \\
\hline New Mexico & Ordered & March 16 & March 26 & 336,263 \\
\hline New York & Ordered & March 18 & May 1 & $2,729,776$ \\
\hline North Carolina & Ordered & March 16 & April 24 & $1,550,062$ \\
\hline North Dakota & Ordered & March 16 & May 1 & 109,706 \\
\hline Ohio & Ordered & March 17 & April 20 & $1,710,143$ \\
\hline Oklahoma & Ordered & March 17 & March 25 & 693,903 \\
\hline Oregon & Ordered & March 16 & April 8 & 606,277 \\
\hline Pennsylvania & Ordered & March 16 & April 9 & $1,727,497$ \\
\hline Puerto Rico & Ordered & March 16 & April 24 & 365,181 \\
\hline Rhode Island & Ordered & March 23 & April 23 & 142,150 \\
\hline South Carolina & Ordered & March 16 & April 22 & 771,250 \\
\hline South Dakota & Recommended & March 16 & April 6 & 136,302 \\
\hline Tennessee & Recommended & March 20 & April 15 & $1,001,562$ \\
\hline Texas & Ordered & March 23 & April 17 & $5,360,849$ \\
\hline Utah & Ordered & March 16 & April 14 & 659,801 \\
\hline Vermont & Ordered & March 18 & March 26 & 88,428 \\
\hline Virginia & Ordered & March 16 & March 23 & $1,287,026$ \\
\hline Washington & Ordered & March 17 & April 6 & $1,101,711$ \\
\hline West Virginia & Ordered & March 16 & April 21 & 273,855 \\
\hline Wisconsin & Ordered & March 18 & April 16 & 864,432 \\
\hline Wyoming & Closure expired & March 16 & $\mathrm{n} / \mathrm{a}$ & 94,170 \\
\hline
\end{tabular}

Notes: Data come from Education Week's “Coronavirus and School Closures” website, last updated on May 15, 2020. All closure dates refer to 2020.

Table A.4

Income, school rurality and race.

\begin{tabular}{|c|c|c|c|c|}
\hline & $\begin{array}{c}\text { School- } \\
\text { centered } \\
\text { resources } \\
(1)\end{array}$ & $\begin{array}{c}\text { Parent- } \\
\text { centered } \\
\text { resources } \\
(2)\end{array}$ & $\begin{array}{c}\text { Google } \\
\text { Classroom } \\
(3)\end{array}$ & $\begin{array}{c}\text { Khan } \\
\text { Academy } \\
(4)\end{array}$ \\
\hline Post-Covid * Household income & $\begin{array}{l}0.10^{* *} \\
(0.04)\end{array}$ & $\begin{array}{l}0.07^{* * *} \\
(0.01)\end{array}$ & $\begin{array}{c}0.06 \\
(0.04)\end{array}$ & $\begin{array}{l}0.04^{* *} \\
(0.02)\end{array}$ \\
\hline Post-Covid ${ }^{*}$ Fraction of schools in rural areas & $\begin{array}{c}-0.08^{* * * *} \\
(0.03)\end{array}$ & $\begin{array}{c}-0.02^{* *} \\
(0.01)\end{array}$ & $\begin{array}{c}-0.13^{* * * *} \\
(0.04)\end{array}$ & $\begin{array}{c}-0.05^{* * * *} \\
(0.02)\end{array}$ \\
\hline Post-Covid * Fraction of students who are Black & $\begin{array}{c}-0.07^{* *} \\
(0.03)\end{array}$ & $\begin{array}{c}-0.04^{* * *} \\
(0.01)\end{array}$ & $\begin{array}{l}-0.00 \\
(0.03)\end{array}$ & $\begin{array}{c}-0.05^{* * *} \\
(0.01)\end{array}$ \\
\hline $\mathrm{N}$ & 50,400 & 50,400 & 50,400 & 50,400 \\
\hline
\end{tabular}

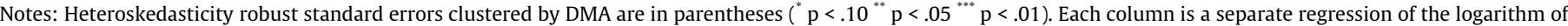

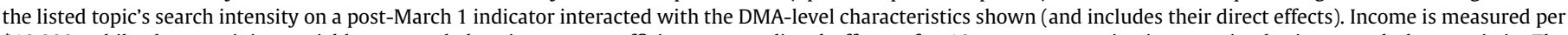

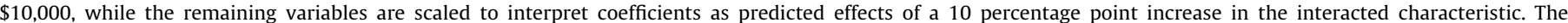

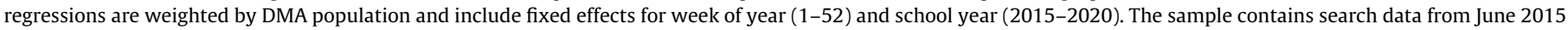
through May 2020, excluding March 2020 and weeks with major school holidays. 
Table A.5

Changes in search intensity, by socioeconomic status quartile.

\begin{tabular}{|c|c|c|c|c|}
\hline & $\begin{array}{l}\text { School- } \\
\text { centered } \\
\text { resources } \\
(1)\end{array}$ & $\begin{array}{l}\text { Parent- } \\
\text { centered } \\
\text { resources } \\
(2)\end{array}$ & $\begin{array}{c}\text { Google } \\
\text { Classroom } \\
(3)\end{array}$ & $\begin{array}{c}\text { Khan } \\
\text { Academy } \\
\text { (4) }\end{array}$ \\
\hline Post-Covid * Top SES quartile & $\begin{array}{l}0.87^{* * *} \\
(0.13)\end{array}$ & $\begin{array}{l}0.54^{* * *} \\
(0.03)\end{array}$ & $\begin{array}{l}1.07^{* * *} \\
(0.13)\end{array}$ & $\begin{array}{l}0.57^{* * *} \\
(0.06)\end{array}$ \\
\hline Post-Covid * 3rd SES quartile & $\begin{array}{l}0.55^{* * *} \\
(0.09)\end{array}$ & $\begin{array}{l}0.38^{* * *} \\
(0.04)\end{array}$ & $\begin{array}{l}0.78^{* * * *} \\
(0.07)\end{array}$ & $\begin{array}{l}0.44^{* * * *} \\
(0.05)\end{array}$ \\
\hline Post-Covid * 2nd SES quartile & $\begin{array}{l}0.39^{* * *} \\
(0.07)\end{array}$ & $\begin{array}{l}0.31^{* * *} \\
(0.02)\end{array}$ & $\begin{array}{l}0.72^{* * *} \\
(0.11)\end{array}$ & $\begin{array}{l}0.43^{* * *} \\
(0.04)\end{array}$ \\
\hline Post-Covid *Bottom SES quartile & $\begin{array}{l}0.23^{* * *} \\
(0.06)\end{array}$ & $\begin{array}{l}0.14^{* * * *} \\
(0.02)\end{array}$ & $\begin{array}{l}0.46^{* * *} \\
(0.06)\end{array}$ & $\begin{array}{l}0.21^{* * * *} \\
(0.04)\end{array}$ \\
\hline Top SES quartile & $\begin{array}{c}-0.17^{* *} \\
(0.08)\end{array}$ & $\begin{array}{c}-0.11^{* *} \\
(0.04)\end{array}$ & $\begin{array}{l}-0.15 \\
(0.11)\end{array}$ & $\begin{array}{c}0.01 \\
(0.06)\end{array}$ \\
\hline 3rd SES quartile & $\begin{array}{c}0.06 \\
(0.06)\end{array}$ & $\begin{array}{l}-0.09^{*} \\
(0.05)\end{array}$ & $\begin{array}{l}-0.03 \\
(0.12)\end{array}$ & $\begin{array}{c}0.01 \\
(0.09)\end{array}$ \\
\hline 2nd SES quartile & $\begin{array}{l}-0.14^{*} \\
(0.08)\end{array}$ & $\begin{array}{c}-0.22^{* * *} \\
(0.07)\end{array}$ & $\begin{array}{c}-0.37^{* *} \\
(0.14)\end{array}$ & $\begin{array}{l}-0.07 \\
(0.05)\end{array}$ \\
\hline $\mathrm{N}$ & 50,400 & 50,400 & 50,400 & 50,400 \\
\hline
\end{tabular}

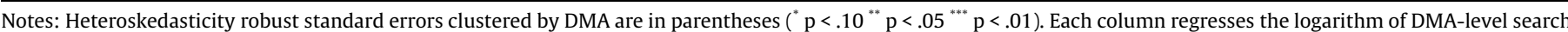

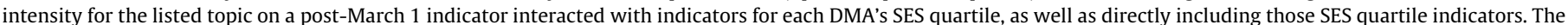

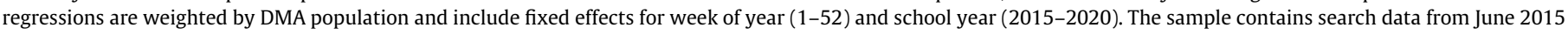
through May 2020, excluding March 2020 and weeks with major school holidays.

Table A.6

Changes in search intensity by socioeconomic status and census region.

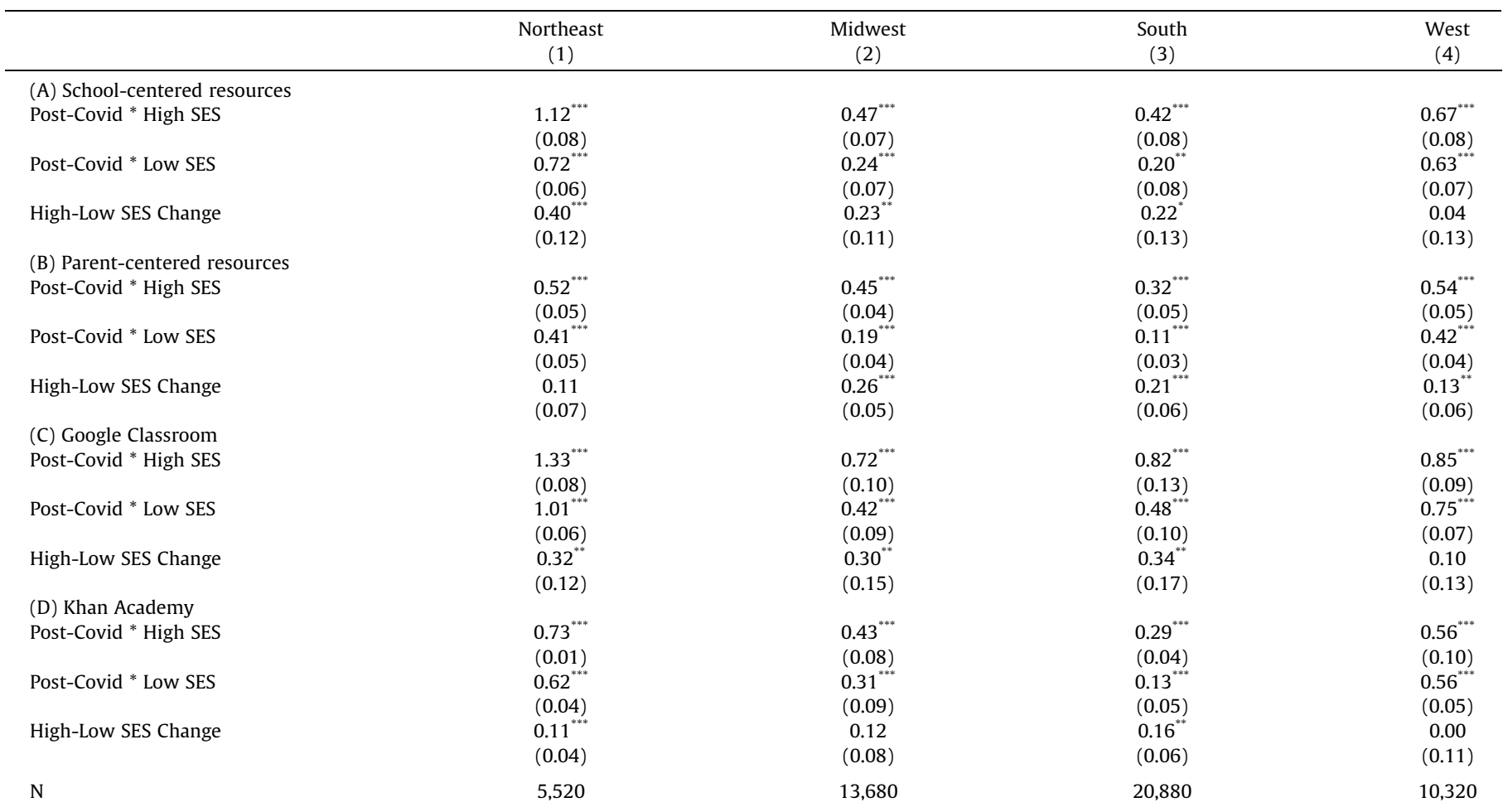

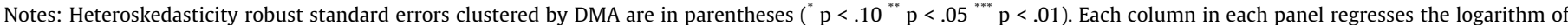

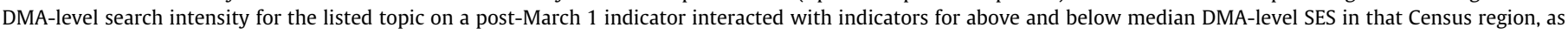

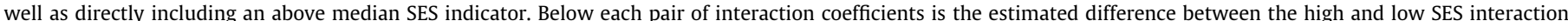

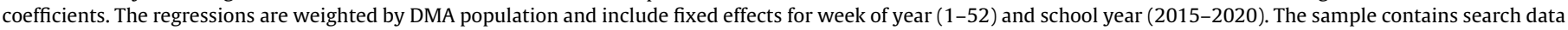
from June 2015 through May 2020, excluding March 2020 and weeks with major school holidays. 
Table A.7

Changes in search intensity, excluding low search areas.

\begin{tabular}{|c|c|c|c|c|}
\hline & $\begin{array}{l}\text { School- } \\
\text { centered } \\
\text { resources } \\
(1)\end{array}$ & $\begin{array}{c}\text { Parent- } \\
\text { centered } \\
\text { resources } \\
(2)\end{array}$ & $\begin{array}{c}\text { Google } \\
\text { Classroom } \\
(3)\end{array}$ & $\begin{array}{c}\text { Khan } \\
\text { Academy } \\
(4)\end{array}$ \\
\hline $\begin{array}{l}\text { (A) Nationwide } \\
\text { Post-Covid }\end{array}$ & $\begin{array}{l}0.52^{* * *} \\
(0.05)\end{array}$ & $\begin{array}{l}0.35^{* * *} \\
(0.02)\end{array}$ & $\begin{array}{l}0.76^{* * *} \\
(0.05)\end{array}$ & $\begin{array}{l}0.41^{* * *} \\
(0.03)\end{array}$ \\
\hline $\begin{array}{l}\text { (B) By median SES } \\
\text { Post-Covid * High SES }\end{array}$ & $\begin{array}{l}0.74^{* * *} \\
(0.08)\end{array}$ & $\begin{array}{l}0.48^{* * *} \\
(0.03)\end{array}$ & $\begin{array}{l}0.94^{* * *} \\
(0.08)\end{array}$ & $\begin{array}{l}0.51^{* * *} \\
(0.05)\end{array}$ \\
\hline Post-Covid * Low SES & $\begin{array}{l}0.30^{* * *} \\
(0.05)\end{array}$ & $\begin{array}{l}0.21^{* * *} \\
(0.02)\end{array}$ & $\begin{array}{l}0.59^{* * *} \\
(0.07)\end{array}$ & $\begin{array}{l}0.30^{* * * *} \\
(0.03)\end{array}$ \\
\hline High SES & $\begin{array}{l}-0.04 \\
(0.06)\end{array}$ & $\begin{array}{c}-0.12^{* * *} \\
(0.03)\end{array}$ & $\begin{array}{c}0.07 \\
(0.10)\end{array}$ & $\begin{array}{c}0.01 \\
(0.06)\end{array}$ \\
\hline High-Low SES Change & $\begin{array}{l}0.44^{* * *} \\
(0.10)\end{array}$ & $\begin{array}{l}0.27^{* * *} \\
(0.03)\end{array}$ & $\begin{array}{l}0.35^{* * *} \\
(0.11)\end{array}$ & $\begin{array}{l}0.21^{* * * *} \\
(0.05)\end{array}$ \\
\hline $\begin{array}{l}\text { (C) By income, online access, race } \\
\text { Post-Covid * Household income }\end{array}$ & $\begin{array}{l}0.15^{* * *} \\
(0.03)\end{array}$ & $\begin{array}{l}0.09^{* * *} \\
(0.01)\end{array}$ & $\begin{array}{l}0.13^{* * *} \\
(0.03)\end{array}$ & $\begin{array}{l}0.08^{* * *} \\
(0.02)\end{array}$ \\
\hline Post-Covid ${ }^{*}$ Broadband penetration rate & $\begin{array}{l}0.43^{* * *} \\
(0.08)\end{array}$ & $\begin{array}{l}0.34^{* * * *} \\
(0.03)\end{array}$ & $\begin{array}{l}0.36^{* * *} \\
(0.09)\end{array}$ & $\begin{array}{l}0.30^{* * * *} \\
(0.05)\end{array}$ \\
\hline Post-Covid ${ }^{*}$ Computer penetration rate & $\begin{array}{l}0.54^{* * *} \\
(0.10)\end{array}$ & $\begin{array}{l}0.46^{* * * *} \\
(0.04)\end{array}$ & $\begin{array}{l}0.47^{* * *} \\
(0.10)\end{array}$ & $\begin{array}{l}0.38^{* * *} \\
(0.07)\end{array}$ \\
\hline Post-Covid ${ }^{*}$ Fraction of schools in rural areas & $\begin{array}{c}-0.18^{* * *} \\
(0.03)\end{array}$ & $\begin{array}{c}-0.10^{* * *} \\
(0.01)\end{array}$ & $\begin{array}{c}-0.19^{* * *} \\
(0.03)\end{array}$ & $\begin{array}{c}-0.10^{* * *} \\
(0.02)\end{array}$ \\
\hline Post-Covid * Fraction of students who are Black & $\begin{array}{c}-0.09^{* * *} \\
(0.03)\end{array}$ & $\begin{array}{c}-0.04^{* * *} \\
(0.02)\end{array}$ & $\begin{array}{l}-0.02 \\
(0.04)\end{array}$ & $\begin{array}{c}-0.06^{* * *} \\
(0.02)\end{array}$ \\
\hline $\mathrm{N}$ & 45,845 & 40,829 & 45,682 & 44,240 \\
\hline
\end{tabular}

Notes: Heteroskedasticity robust standard errors clustered by DMA are in parentheses ( $\left.\mathrm{p}<.1{ }^{* *} \mathrm{p}<.05^{* * *} \mathrm{p}<.01\right)$. In panel A, each column regresses the logarithm of the listed topic's search intensity on a post-March 1 indicator. Panel B interacts the post indicator with above and below median SES indicators. Below each pair of interaction coefficients in panel B is the estimated difference between the high and low SES interaction coefficients. Each coefficient in Panel C comes from a separate regression that interacts the post indicator with DMA-level household mean income or the other listed resource and demographic measures. Income is measured per $\$ 10,000$, while the remaining variables are scaled to interpret coefficients as predicted effects of a 10 percentage point increase in the interacted characteristic. The regressions are weighted by DMA population and include fixed effects for week of year (1-52) and school year (2015-2020). The sample contains search data from June 2015 through May 2020, excluding March 2020 and weeks with major school holidays, as well as DMAs with low search intensity in any given week.

Table A.8

Changes in search intensity by median SES.

\begin{tabular}{|c|c|c|c|c|}
\hline & $\begin{array}{l}\text { School- } \\
\text { centered } \\
\text { resources } \\
(1)\end{array}$ & $\begin{array}{c}\text { Parent- } \\
\text { centered } \\
\text { resources } \\
(2)\end{array}$ & $\begin{array}{c}\text { Google } \\
\text { Classroom } \\
(3)\end{array}$ & $\begin{array}{c}\text { Khan } \\
\text { Academy } \\
(4)\end{array}$ \\
\hline Post-Covid * High SES & $\begin{array}{l}0.66^{* * *} \\
(0.07)\end{array}$ & $\begin{array}{l}0.46^{* * *} \\
(0.03)\end{array}$ & $\begin{array}{l}0.85^{* * *} \\
(0.08)\end{array}$ & $\begin{array}{l}0.48^{* * *} \\
(0.05)\end{array}$ \\
\hline Post-Covid * Low SES & $\begin{array}{l}0.35^{* * *} \\
(0.04)\end{array}$ & $\begin{array}{l}0.22^{* * * *} \\
(0.02)\end{array}$ & $\begin{array}{l}0.66^{* * *} \\
(0.06)\end{array}$ & $\begin{array}{l}0.33^{* * *} \\
(0.03)\end{array}$ \\
\hline High-Low SES Change & $\begin{array}{l}0.31^{* * *} \\
(0.08)\end{array}$ & $\begin{array}{l}0.25^{* * *} \\
(0.03)\end{array}$ & $\begin{array}{l}0.19^{* *} \\
(0.10)\end{array}$ & $\begin{array}{l}0.15^{* *} \\
(0.06)\end{array}$ \\
\hline
\end{tabular}

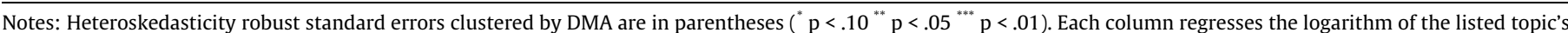

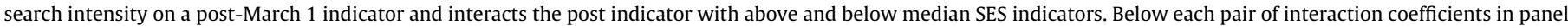

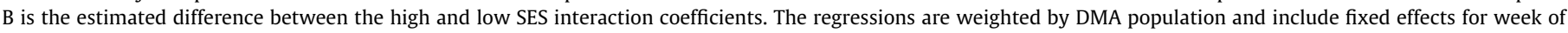

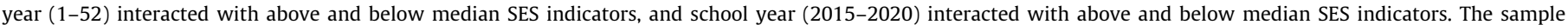
contains search data from June 2015 through May 2020, excluding March 2020 and weeks with major school holidays.

\section{References}

Aucejo, E.M., French, J.F., Araya, M.P.U., Zafar, B., 2020. The impact of COVID-19 on student experiences and expectations: Evidence from a survey. NBER Working Paper 27392.

Barnum, M., Bryan, C., 2020. America's great remote-learning experiment: What surveys of teachers and parents tell us about how it went. Chalkbeat.

Bucy, E.P., 2000. Social access to the internet. Harvard Int. J. Press/Polit. 5 (1), 50-61.

Chetty, R., Friedman, J.N., Hendren, N., Stepner, M., 2020. Real-time economics: a new platform to track the impacts of COVID-19 on people, businesses, and communities using private sector data. NBER Working Paper 27431.

Choi, H., Varian, H., 2012. Predicting the present with Google Trends. Econ. Rec. 88, $2-9$.
Cleveland, C., 2020. Toward reopening: What will school look like this fall? EducationNext.

Das, J., Dercon, S., Habyarimana, J., Krishnan, P., Muralidharan, K., Sundararaman, V., 2013. School inputs, household substitution, and test scores. Am. Econ. J.: Appl. Econ. 5 (2), 29-57.

Goldsmith-Pinkham, P., Sojourner, A., 2020. Predicting initial unemployment insurance claims using Google Trends. Working Paper.

Hamilton, L.S., Grant, D., Kaufman, J.H., Diliberti, M., Schwartz, H.L., Hunter, G.P., Messan Setodji, C., Young, C.J., 2020. COVID-19 and the state of K-12 schools: Results and technical documentation from the spring 2020 American educator panels COVID-19 surveys. RAND Research Report.

Horowitz, J., 2020. Lower-income Parents Most Concerned about their Children Falling behind Amid COVID-19 School Closures. Pew Research Center. 
Houtenville, A.J., Conway, K.S., 2008. Parental effort, school resources, and student achievement. J. Hum. Resour. 43 (2), 437-453.

Jæger, M.M., Blaabæk, E.H., 2020. Inequality in learning opportunities during Covid-19: evidence from library takeout. Res. Soc. Stratif. Mob. 100524.

Jones, S., Johnson-Yale, C., Millermaier, S., Pérez, F.S., 2009. US college students' internet use: race, gender and digital divides. J. Comput.-Mediated Commun. 14 (2), 244-264.

Kearney, M.S., Levine, P.B., 2015. Media influences on social outcomes: the impact of MTV's 16 and Pregnant on teen childbearing. Am. Econ. Rev. 105 (12), 3597MTV's

Kuhfeld, M., Soland, J., Tarasawa, B., Johnson, A., Ruzek, E., Liu, J., 2020. Projecting the potential impacts of COVID-19 school closures on academic achievement. Annenberg Institute Working Paper 20-226.

Lake, R., Dusseault, B., 2020. Remote Classes are in Session for More School Districts, but Attendance Plans are Still Absent. Center on Reinventing Public Education.

Malkus, N., 2020. School districts' remote-learning plans may widen student achievement gap. EducationNext.
Polgreen, P.M., Chen, Y., Pennock, D.M., Nelson, F.D., Weinstein, R.A., 2008. Using internet searches for influenza surveillance. Clin. Infect. Diseases 47 (11), 14431448.

Pop-Eleches, C., Urquiola, M., 2013. Going to a better school: effects and behavioral responses. Am. Econ. Rev. 103 (4), 1289-1324.

Rice, R.E., Haythornthwaite, C., 2006. Perspectives on Internet use: Access, Involvement and Interaction. The Handbook of New Media, pp. 92-113.

Schneider, M., Buckley, J., 2002. What do parents want from schools? evidence from the internet. Educ. Eval. Policy Anal. 24 (2), 133-144.

Stephens-Davidowitz, S., 2014. The cost of racial animus on a black candidate: Evidence using Google search data. J. Public Econ. 118, 26-40.

Vigdor, J.L., Ladd, H.F., Martinez, E., 2014. Scaling the digital divide: home computer technology and student achievement. Econ. Inquiry 52 (3), 1103-1119.

von Hippel, P., 2020. How will the coronavirus crisis affect children's learning? Unequally. EducationNext. 